\title{
Rei natural, rei feudal, rei cavaleiro: os primeiros anos do rei Jaime I, o Conquistador
}

\author{
LUCIANO JOSÉ VIANNA ${ }^{1}$
}

Universitat Autònoma de Barcelona

\section{INTRODUÇÃO}

Jaime I é conhecido como o Conquistador, cognome que lhe foi legado pelas conquistas que realizou durante seu reinado. Entretanto, ao lermos a narrativa do Livro dos Feitos, conjecturamos que foi a partir da conquista de Maiorca, realizada em 1229 diante dos muçulmanos, que o rei recebeu esta designação.

E antes desta conquista? Como Jaime I se representou nos primeiros anos de sua vida? Como o rei, ao refletir sobre seu passado, construiu sua imagem em suas memórias? Para responder a estas perguntas devemos observar os primeiros capítulos do Livro dos Feitos (1 a 46) e analisar as palavras do rei sobre si mesmo, ou seja, palavras oriundas de uma reflexão posterior aos fatos ocorridos em sua vida e que o rei desejou que fossem mantidas para a posteridade.

Desse modo, em nossa opinião, os primeiros capítulos sobre a vida do Conquistador giram em torno de uma tentativa de legitimação onde identificamos que o rei nos apresenta suas três facetas: um rei natural, um rei feudal e um rei cavaleiro. Em nossa opinião, a narrativa do Livro dos Feitos em relação a este momento da vida do rei contém uma particularidade no sentido de legitimar a autoridade de Jaime I, o que o fortaleceria, posteriormente, como o Conquistador ${ }^{2}$.

1 Aluno do curso de Doutorado «Cultures en contacte a la Mediterrànea» do Departament de Ciències de l'Antiguitat i de l'Edat Mitjana da Universitat Autònoma de Barcelona (UAB). Bolsista (BCC) da Agència de Gestió d' Ajuts Universitaris i de Recerca (AGAUR) 2008-2010. Membro do Instituto Brasileiro de Filosofia e Ciência Raimundo Lúlio (IBFCRL).

${ }^{2}$ Este artigo é parte de nosso trabalho de Mestrado intitulado «Pelos céus e pela terra: a conquista de Maiorca (1229) como legitimidade do rei Jaime I, o Conquistador (1208-1276)» defendido e aprovado em Agosto de 2009 no Programa de Pós-Graduação em História Social das Relações Políticas da Universidade Federal do Espírito Santo (UFES). Para um estudo sobre os primeiros anos do rei Jaime, ver Pujol, Josep M. «El mite de l'heroi a la casa de Barcelona: Guifred I el Pelós i Jaume I». Bargalho, Maria e Zaragoza, Joana (Eds.). Mites i llegendes. Cossetània Edicions, 2002, p. 113-133. 


\section{UM REINO E O SEU REI NATURAL}

Faz muito tempo que o medievalista Jacques Le Goff disse que a infância é um momento decisivo, tanto na história das civilizações quanto na história dos indivíduos; e por ser um momento decisivo, os primeiros anos são muito importantes e definitivos para os anos vindouros ${ }^{3}$. Da mesma forma poderíamos comparar os primeiros capítulos das memórias de Jaime I como decisivos para sua história e que muitas de suas atitudes nestes capítulos iniciais foram determinantes para sua formação como o Conquistador.

Os primeiros capítulos do Livro dos Feitos apresentam um resumo sobre os acontecimentos iniciais da vida de Jaime I. Além disso, compreendemos que os mesmos possuem uma forte característica simbólica e que foram utilizados para demonstrar a existência da legitimidade de Jaime ainda nos primeiros anos de seu reinado como um rei natural.

Os símbolos representam o núcleo dos sistemas culturais, uma vez que é através deles que são formados os pensamentos, as idéias e as representações da realidade ${ }^{4}$. Além disso, o simbolismo, ou seja, a representação por meio de símbolos era a forma padrão pela qual os medievais expressavam sua realidade 5 . Dessa forma, nesta primeira parte do artigo tentaremos nos aproximar dos significados simbólicos presentes no Livro dos Feitos para compreendermos como o rei se representou com a intenção de legitimar-se perante seus nobres e diante de sua linhagem. Contudo, para realizar essa proposta de compreensão devemos sair de nós mesmos e estar disponíveis a escutar o que o outro tem a nos dizer, a nos revelar, e assim sermos enriquecidos ao nos propormos a escutar, a dialogar com o outro 6 . Será, então, partindo desta postura que analisaremos as palavras e os gestos transmitidos por Jaime I por meio de seu Livro.

\subsection{O reconhecimento dos céus: o simbolismo celeste}

Quando um rei medieval iniciava seu reinado deveria alcançar dois objetivos. O primeiro era obter a potestas, ou seja, a possibilidade de obter um poder e utilizá-lo durante seu reinado. Conseguir este poder dependia única e exclusi-

${ }^{3}$ LE Goff, Jacques, A civilização do Ocidente medieval. v. 2. Lisboa: Estampa, 1995, p. 4-5.

${ }^{4}$ JoHnson, Allan G., The Blackwell dictionary of sociology: a user's guide to sociological language. Cambridge: Blackwell, 1995, p. 321.

5 FrANCO JÚNIOR, Hilário, A Idade Média: nascimento do Ocidente. São Paulo: Brasiliense, 2001, principalmente o capítulo 3 «As estruturas políticas». Para o assunto referente a esta primeira parte deste artigo, ver VIANNA, Luciano J. «Simbolismo e naturalidade nos primeiros tempos do reinado de Jaime I (1208-1276), o Conquistador». XIV Seminario Académico APEC. Compartiendo el Conocimiento. Barcelona: Casa Amèrica Catalunya, 2009, p. 109-118. Ver também VIANNA, Luciano J. «Passado, simbolismo e naturalidade: os primeiros anos de Jaime I (1208-1276) no Livro dos Feitos». Temporalidades - Revista de História, v.1, p. 195-214, 2009.

${ }^{6}$ Fernandes, Raúl Cesar Gouveia, Reflexões sobre o Estudo da Idade Média. LaUand, Luiz Jean (coord.), Revista VIDETUR, n. ${ }^{\circ}$ 6, 1999. Disponível em: http://www.hottopos.com.br/ videtur6/raul.htm. Acesso em 16 de Fevereiro de 2008. 
vamente do rei, de sua personalidade, coragem e inteligência. Assim, segundo Villacañas, um rei era uma potestade, mas nem sempre uma autoridade; detinha o poder, mas não o exercia, detinha a potestas, mas não a auctoritas. No caso de Jaime I, levando em consideração o ambiente feudal dos primeiros anos de seu reinado, isso é fato. Assim, para obter a autoridade que necessitava, um rei devia conquistá-la ao longo de sua vida por meio das ações que realizava. $\mathrm{O}$ segundo elemento era a continuidade da linhagem, a qual confirmava e autorizava o acesso do rei ao trono ${ }^{7}$. A importância da linhagem para Jaime I, o décimo quarto conde de Barcelona (como ele mesmo se afirmou no Livro dos Feitos) ${ }^{8}$, se faz presente em toda a narrativa de sua obra, onde o rei referiu-se à mesma não somente no sentido de comprovar a sua legitimidade, mas também no sentido de superar os feitos e realizações de seus antecessores ${ }^{9}$. Superando seus antepassados e realizando os feitos que os mesmos não realizaram Jaime se afirmaria como rei.

O que nos diz a narrativa do Livro dos Feitos? Antes de ter sido jurado nas Cortes Gerais de Lérida em 1214, Jaime destacou em suas memórias uma situação que o confirmaria como rei natural, um seyor natural legitimado pelos céus. Referimo-nos aqui ao momento logo após seu nascimento, quando o rei, ainda menino, fora levado à Igreja de Nossa Senhora, ou Notre-Dame das Madeiras. Eis o que aconteceu:

E nossa mãe, assim que nascemos, enviou-nos à Santa Maria, levando-nos nos braços e dizendo as matinas na igreja de Nossa Senhora. E assim que nós passamos pelo portal, cantaram Te Deum laudamus. Os clérigos não sabiam que nós iríamos entrar ali, mas nós entramos quando eles cantavam aquele cântico ${ }^{10}$.

No instante em que Jaime fora introduzido na Igreja de Santa Maria, lugar supremo onde o poder sagrado estava presente, os clérigos cantaram Te Deum Laudamus, um hino litúrgico. Entretanto, pela leitura da narrativa, compreendemos que aquele cântico entoado pelos clérigos era direcionado para louvar o Rei Celeste, que governava reino dos céus. Curiosamente, o rei fez questão de lembrar em suas memórias que os clérigos não sabiam que ele seria introduzido naquele lugar sagrado. Este detalhe acrescentado pelo rei no seu relato faz com que o reconhecimento dos céus em relação a Jaime como um rei continuador de sua linhagem seja ainda mais forte ${ }^{11}$.

7 Villacañas, José Luis, Jaume I el Conquistador. Barcelona: Espasa Calpe, 2004, p. 19.

${ }^{8}$ Llibre dels Fets del Rei En Jaume. 2 vol. (A cura de Jordi Bruguera). Barcelona: Barcino, 1991. Tradução de Ricardo da Costa (Ufes) e Luciano José Vianna com base na edição acima e confrontada com Jaime I. Libro de los hechos (Introducción, traducción y notas de Julia Butiñá Jiménez). Madrid: Gredos, 2003. Atualmente a tradução para o português se encontra no processo de revisão.

9 Cingolani, Stefano Maria, La memòria dels reis. Les Quatre Grans Cròniques i la historiografia catalana, des del segle X fins al XIV. Barcelona: Base, 2008, p. 37. Ver também o artigo CINGOLANI, Stefano Maria. Seguir les vestígies dels antecessors. Llinatge, reialesa i historiografia a Catalunya de Ramon Berenguer IV a Pere II (1131-1285). Anuario de Estudios Medievales, Barcelona, Consejo Superior de Investigaciones Científicas, v. 1, n. ${ }^{\circ}$ 36, p. 201-240, 2006.

${ }_{10}$ Llibre dels Fets del Rei En Jaume, op. cit., cap. 5, nota 8.

11 Vianna, Luciano J., op. cit., p. 195-214, nota 5. 
Imaginemos: como Jaime supostamente interpretou aquele acontecimento? Provavelmente, ao introduzir este fato em sua narrativa, Jaime interpretou aquela coincidência como um sinal favorável ao seu reconhecimento como rei: um reconhecimento celeste. Assim, já no início de sua narrativa, o rei apresentou-se como um continuador da linhagem, legitimado pelos sinais simbólicos que acompanharam seu nascimento e que assinalavam um bom desígnio divino para ele $^{12}$.

Para compreendermos as palavras de Jaime I devemos ter em mente que, levando em consideração o contexto ao qual os primeiros capítulos do Livro dos Feitos se referem, ao construir sua narrativa Jaime tinha a consciência de que necessitava de legitimar-se tanto em relação ao passado (como conde da casa de Barcelona) quanto ao presente (perante os seus nobres). Para isso, reconstruiu seu nascimento envolvido por uma concepção religiosa onde as forças celestes intervieram e transformaram aquele momento em uma interseção entre o céu e a terra. Dessa forma, Jaime articulou elementos que poderiam legitimá-lo perante sua linhagem e perante seus nobres e inseriu os mesmos em sua narrativa.

O que aqui nos interessa é o simbolismo transcendental do momento, algo que ligou a imagem de Jaime I aos céus. O rei, ainda uma criança, pois o levavam «nos braços», estava em uma igreja, um ambiente religioso. E nesse mesmo momento iniciou-se um cântico de louvor a Deus: assim, Jaime I apresenta-se no início da narrativa do Livro dos Feitos como um rei que era louvado na terra e que era reconhecido pelos céus.

Em uma época em que o poder do rei devia obrigatoriamente ser reconhecido pelo supremo poder de Deus, o simbolismo assumia um significado muito forte. Por exemplo, Marc Bloch demonstrou isso ao analisar todo o processo da crença de que os reis possuíam o poder de curar as escrófulas através do toque real. Segundo Bloch, esse milagre foi a expressão de uma concepção particular de poder político supremo ${ }^{13}$.

Voltamos nosso olhar para o contexto historiográfico da época. Antes do século XIII, as obras históricas compostas no território catalão eram escritas em latim e consistiam em breves anotações sobre os acontecimentos históricos. Posteriormente, recolheram também alguns fatos relacionados à monarquia francesa ou aos condados catalães. Por exemplo, a Gesta Comitum Barcinonensium, um dos textos fundadores da historiografia catalã, surgiu em um primeiro momento durante o reinado de Afonso II, o Casto (1162-1196) e seu conteúdo expõe a necessidade de estabelecer uma ligação genealógica, real ou imaginária, com o conde Guifredo, o Peludo (878-897). Escrita inicialmente em latim e produzida no monastério de Ripoll, a Gesta analisa a sucessão cronológica dos condes de Barcelona, destacando sucintamente os principais acontecimentos de cada reinado ${ }^{14}$.

${ }^{12}$ SOler I LlOPART, Albert, Literatura catalana medieval. Barcelona: UOC, 2003, p. 21.

${ }_{13}$ BLOCH, Marc, Os reis taumaturgos. São Paulo: Companhia das Letras, 1993.

14 Aurell, Jaume, From genealogies to chronicles: the power of the form in medieval catalan historiography. Viator, Berkeley, n. ${ }^{\circ}$ 36, p. 235-264, 2005. Ver também Spiegel, Gabrielle M. Genealogy: Form and Function in Medieval Historical Narrative. History and Theory, Middletown, v. 22 , n. ${ }^{\circ} 1$, p. $43-53,1983$. 
Já no decorrer do século XIII, a produção literária vernacular se fortaleceu e foram compostas crônicas sobre os fatos históricos mais recentes, utilizando a experiência dos escritores e também os fatos vividos pelos próprios cronistas ${ }^{15}$. Foi assim que surgiram as Quatro Grandes Crônicas da literatura catalã, as quais formam um corpo historiográfico compreendido entre os séculos XIII e XIV. ${ }^{16}$

Diferentemente da função genealógica apresentada na Gesta Comitum Barcinonensium ${ }^{17}$, o Livro dos Feitos oferece uma visão contemporânea dos fatos. Nesta obra, Jaime I narrou os acontecimentos do seu reinado e sua interpretação dos mesmos. Expressado em uma língua vernacular, o Livro dos Feitos apresenta a vida de Jaime I e como este evocou seu passado. Com isso, o rei transportou seu passado para o presente, falou especificamente da sua vida e destacou suas interpretações com o intuito de legitimar-se.

Voltamos nosso olhar para a narrativa: essa legitimação, esse simbolismo transcendental foi confirmado em outro momento, dessa vez na Igreja de São Firmino:

Depois disso nos levaram para São Firmino. E quando aqueles que nos levavam entraram na igreja de São Firmino, cantavam Benedictus Dominus Deus Israel. E quando nos levaram de volta para a casa de nossa mãe, ela ficou muito alegre com esses prognósticos ocorridos conosco ${ }^{18}$.

Maria de Montpelier (1180-1213), mãe de Jaime I, ficou feliz ao saber de todos os presságios que aconteceram com seu filho, os quais confirmaram que ele era reconhecido por Deus, seu senhor feudal por excelência ${ }^{19}$. Assim, Jaime I estaria preparado espiritualmente para enfrentar os problemas que surgiriam durante seu reinado. Mais que isso: tinha toda a proteção celeste para empreender o governo de seu reino terrestre.

Porque a narrativa nos apresenta todos estes acontecimentos localizados no início do seu reinado? Talvez um sinal que podemos seguir para encontrar uma possível resposta seja o momento da vida de Jaime em que tudo isso ocorreu e que foi relatado em seu Livro. Assim, ao analisarmos esta fonte, devemos não somente destacar a importância de ser reconhecido pelos céus, mas também o momento em que isso ocorreu na vida de Jaime I: sua infância.

Depois de certo tempo, tornou-se costume entre os monarcas medievais coroarem ou sagrarem seus filhos antes mesmo que estes iniciassem seus reina$\operatorname{dos}^{20}$. Isso aconteceu com Jaime I? Vejamos: Pedro, o Católico (1196-1213) e

${ }^{15}$ MachiRANT, Francesc, «Introducció». Llibre dels fets. Jaume I. Alzira: Bromera, 2008, p. 15.

16 SoldeVILA, Ferran, «Introducció a les Quatre Grans Cròniques». Les Quatre Grans Cròniques. Barcelona: Selecta, 1971, p. 3.

17 Gestes dels comtes de Barcelona i Reis d'Aragó (A cura de Stefano Maria Cingolani). València: Universitat de València/Monuments d'Història de la Corona d'Aragó, 2008.

${ }^{18}$ Llibre dels Fets del Rei En Jaume, op. cit., cap. 5, nota 8.

19 Ver Le Goff, Jacques, O Deus da Idade Média. Rio de Janeiro: Civilização Brasileira, 2007.

${ }^{20}$ Le Goff, Jacques. Rei. In: Le Goff, Jacques. \& Schmitt, Jean-Claude (Coords.). Dicionário Temático do Ocidente Medieval. v. 2. São Paulo: Edusc, 2002, p. 395-414. 
Maria de Montpelier morreram em 1213, quando Jaime tinha somente cinco anos; além disso, o juramento nas Cortes Gerais de Lérida ocorreu em 1214, ou seja, depois da morte de seus pais. Desse modo, o fato de ser levado a uma igreja e ser reconhecido pelos céus (idéia fortalecida devido às coincidências ocorridas) não deve ser visto como um simples evento, mas sim como uma «necessidade» para sua legitimação. Dessa forma, compreendemos que Jaime relatou esta passagem simbólica em seu Livro não somente porque acreditava nela, mas também porque antes mesmo de ter sido jurado pelos seus nobres recebera uma confirmação celeste interpretada pelos acontecimentos que narrou e que aconteceram logo após seu nascimento, difundindo, assim, a idéia de que era um rei escolhido e confirmado por Deus ${ }^{21}$.

Dessa forma, ao afirmar que os feitos do Conquistador estavam adequados às suas crenças, o Livro dos Feitos transformou a historiografia em um legado exemplar e nesse sentido transcendeu a história e referindo-a à vontade de Deus $^{22}$. Mais importante que isso: aqueles simbolismos protegeram não somente a continuidade dinástica dos condes de Barcelona no reino de Aragão, mas também o próprio direito de Jaime I como rei.

Mas Jaime não apresentou somente um simbolismo celeste em relação aos primeiros anos de seu reinado. Os simbolismos terrestres também eram necessários para fortalecer sua autoridade que, antes de tudo, fora legitimada pelos céus. Diante disso, o Livro dos Feitos expõe alguns fatos interessantes sobre o juramento nas Cortes Gerais de Lérida.

\subsection{O juramento nas Cortes Gerais de Lérida: o simbolismo terreno}

Analisando a narrativa, observamos que a cerimônia de juramento do rei nas Cortes Gerais de Lérida pode ser entendida como um simbolismo terreno, pois se referiu à autoridade do rei entre seus nobres. Com a morte dos pais de Jaime I, Pedro, o Católico e Maria de Montpelier, o Papa Inocêncio III (1161-1216) determinou Pedro de Benevento (c. XIII) como legado papal para cuidar dos assuntos referentes aos territórios da Coroa de Aragão. Dessa forma, o representante papal convocou as Cortes Gerais de Lérida para que os nobres, os clérigos e os representantes das cidades jurassem fidelidade ao rei $^{23}$. Eis as palavras do Livro dos Feitos sobre o juramento:

E tiveram outro conselho: que em nosso nome e com um novo selo que mandariam fazer, ordenariam uma corte de catalães e aragoneses em Lérida, na qual também iriam o arcebispo, os bispos, abades, ricos-homens de cada um

${ }^{21}$ Belenguer, Ernest, Jaume I i el seu regnat. Lleida: Pagès Editors, 2007, p. 33.

${ }^{22}$ Hauf, Albert G., «Més sobre la intencionalitat dels textos historiogràfics catalans medievals». Medieval and Renaissance Studies in honour of Robert Brian Tate. Oxford: The Dolphin Book Co., 1986, p. 47-61.

${ }^{23}$ Cawsey, Suzanne F., Reialesa i propaganda. L'eloqüència reial i la Corona d'Aragó, c. 1200-1450. València: Publicacions Universitat de València, 2008, p. 34. 
dos reinos e de cada cidade, e dez homens com a autoridade dos outros para fazer o que fosse necessário. E todos vieram no dia da corte, exceto Dom Fernando e o conde Dom Sancho, pois tinham a esperança que cada um fosse rei. Ali todos juraram que guardariam nosso corpo, nossos membros e nossa terra, e que nos guardariam de todas as coisas e de $\operatorname{todos}^{24}$.

Com a intenção de legitimar-se, Jaime recordou o primeiro juramento feito pelos seus nobres diante da sua pessoa. A partir daquele momento, o poderio de Jaime I seria representado por um selo, decisão tomada na celebração de uma corte composta por catalães, aragoneses, religiosos, ricos-homens e cidadãos. A função do selo seria simbólica, representando Jaime I por toda Coroa de Aragão.

Devemos frisar que esta representação terrena foi a primeira, de acordo com o Livro dos Feitos, que ocorreu com o rei logo no início de seu reinado. Além disso, serviu para difundir a sua legitimidade frente não apenas aos outros reis, mas também diante de seus súditos. Dessa forma, a cerimônia que Jaime recordou em seu Livro representou sua consagração política, apesar de que alguns de seus parentes não o tenham reconhecido inicialmente ${ }^{25}$.

Entretanto, é notório que Jaime I não poderia ser «efetivamente» um rei desde aquele momento; não poderia exercer sua autoridade por ele mesmo. Mesmo com este juramento, o começo do reinado de Jaime I foi muito conturbado, pois as lutas entre os nobres pela disputa do reino são constantemente recordadas no Livro dos Feitos. Além disso, o Conquistador herdou um reino em constante agitação, pois, em suas próprias palavras, quando entrou em Monzón pela primeira vez «não tínhamos sequer do que comer para um dia, pois nossa terra estava destruída e penhorada! $\gg^{26}$ Apesar disso, Jaime se apresenta em seu Livro como um rei que fora auxiliado especialmente pela fortuna e pela visão providencialista da história ${ }^{27}$.

Levando em consideração todos os acontecimentos precoces que aconteceram com Jaime I, o Livro dos Feitos nos passa a informação de que o mesmo acreditava que era um rei natural e que se fundamentava na função do simbolismo que o auxiliava na construção de sua imagem como rei. Recordamos: um simbolismo tanto celeste quanto terrestre que fazia com que o rei estivesse envolvido por um reconhecimento dos céus e da terra já em seus primeiros anos como conde de Barcelona e rei de Aragão.

Ao relacionarmos estes fatos com o reinado de Jaime, entendemos que o rei os comentou por dois motivos: primeiro porque acreditava no significado simbólico dos mesmos e segundo porque necessitava de incluí-los em suas memórias alcançar a legitimidade perante seus nobres e perante sua linhagem, pois, de acordo com o prefácio do Livro dos Feitos, o rei tinha a intenção de ser reconhecido posteriormente por todos:

\footnotetext{
24 Llibre dels Fets del Rei En Jaume, op. cit., cap. 11, nota 8.

25 Villacañas, José Luis, op. cit., p. 62-63, nota 7.

${ }^{26}$ Llibre dels Fets del Rei En Jaume, op. cit., cap. 11, nota 8.

27 Villacañas, José Luis, op. cit., p. 56, nota 7.
} 
E para que os homens conhecessem e soubessem como passamos esta vida mortal e o que nós fizemos com a ajuda do Senhor Poderoso, que é a verdadeira Trindade, deixamos este livro como memória para aqueles que desejam ouvir as graças que Nosso Senhor nos fez e para dar exemplo a todos os outros homens [2r] do mundo para que façam o que nós fizemos: colocar sua fé nesse Senhor que é tão poderoso ${ }^{28}$.

Que todos soubessem as graças que Deus lhe concedera e que suas ações servissem de exemplo para todos os homens do mundo: esta era a vontade de Jaime. Assim, ao recordar os primeiros anos de seu reinado com base nos simbolismos terrestres e celestes, o rei objetivava reforçar textualmente sua imagem perante a nobreza que lhe fazia oposição e planejava legitimar-se textualmente perante sua linhagem. Relacionando estes acontecimentos ao contexto dos primeiros anos de vida do rei, compreendemos que Jaime I acreditava que era um monarca designado por Deus, um rei natural e continuador da sua linhagem, o que dentro da «política medieval» era imprescindível; tudo reforçado pelo poder do simbolismo, o qual fazia com que sua naturalidade como rei fosse reconhecida.

\section{JAIME I COMO REI FEUDAL}

Depois de todas as representações simbólicas (celestes e terrestres) expostas no capítulo anterior, Jaime teria que reinar efetivamente sobre seus nobres e impor sua legitimidade. Como explicamos, quando iniciou seu reinado ele apenas detinha a potestas, mas não a auctoritas, ou seja, não apresentava autoridade para conduzir seu reino.

Agora importa estudarmos as atitudes de Jaime I como um rei feudal, inserindo a narrativa dentro do contexto em que o rei viveu. Antes disso, é preciso lembrar que nossa distância com o passado aumenta o desconhecimento do mesmo. Essa é a primeira medida, a primeira precaução que devemos tomar antes de estudar um rei do século XIII. Nossa distância em relação a Jaime I é justificada pelo simples fato de que ele representa um tipo humano com o qual não temos acesso imediato e tampouco nenhum tipo de elemento para comparação ${ }^{29}$.

Mas como modificar esse quadro, como estabelecer uma ponte com esse passado distante sem desvirtuar seu significado? Como compreender esse momento longínquo? Um caminho a ser seguido é ter como referência o próprio período estudado, metodologia que foi aplicada em pleno século XX. A partir de então, passou-se a olhar a Idade Média com o olhar dela mesma, e não com aqueles que viveram ou viviam outro momento histórico ${ }^{30}$.

Aproximar-se da Idade Média implica não apenas suspender nossos pensamentos modernos, uma vez que eles não eram vigentes naquela época ${ }^{31}$, mas

\footnotetext{
28 Llibre dels Fets del Rei En Jaume, op. cit., cap. 1, nota 8.

29 Villacañas, José Luis, op. cit., p. 19, nota 7.

30 Franco Júnior, Hilário, op. cit., p. 13, nota 5.

31 soler i Llopart, Albert, op. cit., p. 13, nota 12.
} 
também estabelecer um elo com o passado, conexão que será proporcionada por meio da análise das palavras e dos gestos transmitidos por Jaime I e escritos em seu Livro. Assim, o que procuramos aqui é estabelecer uma conexão com o passado, com as palavras de Jaime I para compreendê-lo pela sua própria perspectiva.

\subsection{As Cortes Gerais de Lérida e o cotidiano em Monzón}

Quais seriam os momentos em que Jaime surge na narrativa do Livro dos Feitos como um rei feudal? Seguindo a narrativa, encontramos uma pista para nossa resposta: em 1214, durante a reunião das Cortes Gerais de Lérida, quando o rei ainda era uma criança com seis anos. Novamente, analisamos o trecho do juramento de Jaime I:

E tiveram outro conselho: que em nosso nome e com um novo selo que mandariam fazer, ordenariam uma corte de catalães e aragoneses em Lérida, na qual também iriam o arcebispo, os bispos, abades, ricos-homens de cada um dos reinos e de cada cidade, e dez homens com a autoridade dos outros para fazer o que fosse necessário. E todos vieram no dia da corte, exceto Dom Fernando e o conde Dom Sancho, pois tinham a esperança que cada um fosse rei. Ali todos juraram que guardariam nosso corpo, nossos membros e nossa terra, e que nos guardariam de todas as coisas e de todos ${ }^{32}$.

Primeiramente, após a saída do rei da tutela de Simon de Montfort (c. 11651218), os naturais de Jaime instituíram uma corte de catalães e aragoneses em Lérida, na qual compareceram os representantes da Igreja, os ricos-homens de cada reino e dez representantes de cada cidade para que Jaime fosse apresentado, ou melhor, para que Jaime fosse jurado como rei.

Analisando a passagem destacada, acreditamos que não fora uma simples coincidência que o rei recordara em seu Livro a participação de todos os braços reais que já existiam em sua época e que cada vez mais se fortaleceriam nos governos de seus sucessores ${ }^{33}$. Desse modo, embora tenha alertado que dois de seus parentes não participaram daquela cerimônia, Jaime I recordou o juramento que seus vassalos lhe fizeram, e que assim, já no começo de seu reinado, era reconhecido por todos os representantes da Coroa de Aragão.

Continuando neste mesmo trecho, veremos que uma palavra importante é «juraram», em catalão, juraren. De acordo com o Diccionari català-valencià-balear ${ }^{34}$, jurar, cuja etimologia vem do latim iūrare, significa «afirmar ou prometer apelando a Deus, a coisas sagradas ou a sanções superiores com um testemunho da verdade daquilo que se afirma ou se promete».

${ }^{32}$ Llibre dels Fets del Rei En Jaume, op. cit., cap. 11, nota 8.

${ }^{33}$ Capdeferro, Marcelo, Otra historia de Cataluña. Barcelona: Acervo, 1990, p. 178-189.

${ }_{34}$ Diccionari catalä-valencià-balear. Disponível em: http://dcvb.iecat.net. Acesso em 12 de Março de 2008. 
Desse modo, a cerimônia de consagração real de Jaime I confirmou a ligação do rei com seus vassalos. Conseqüentemente, o contrato vassálico gerava obrigações para ambas as partes ${ }^{35}$. Assim, todos que compareceram às Cortes Gerais de Lérida juraram fidelidade e estabeleceram uma relação vassálica com Jaime I muito mais no sentido de reconhecê-lo e legitimá-lo como continuador da linhagem dos condes de Barcelona que propriamente estabelecer um contrato, pois no juramento não há a contrapartida por parte de Jaime, o que caracterizaria o contrato como sinalagmático, ou seja, recíproco.

Assim, compreendemos que este é o primeiro momento na narrativa do $\mathrm{Li}$ vro dos Feitos que Jaime I pode ser considerado como um rei feudal, mesmo que ainda não pudesse proporcionar a contrapartida do juramento vassálico. No juramento acima identificamos que a preocupação maior referia-se à proteção do rei, o que já implicaria o seu reconhecimento. Isso significa que o juramento foi feito muito mais no sentido de garantir o reino ao rei quando o mesmo retornasse de sua tutela templária que estabelecer uma relação recíproca desde aquele instante.

Depois de sair do castelo de Monzón com aproximadamente nove anos de idade, Jaime participou de diversos combates ${ }^{36}$ e convocou cortes ${ }^{37}$, apresentando um fortalecimento de sua autoridade perante seus vassalos. Não podemos esquecer que o rei, nesses primeiros anos, reinava sobre «bandos e partidas» que já existiam desde a sua permanência no castelo de Monzón:

Quando estávamos em Monzón, levantaram-se bandos e partidas entre os ricoshomens de Aragão. Dom Pedro Ahones, Dom Atorela, Dom Jimeno de Urrea, Dom Arnau Palacin, Dom Bernardo de Benavente e Dom Blasco Massa, e outros que não nos lembramos, além de ricos-homens e cavaleiros, fizeram um bando e uma partida com o conde de Rossilhão, Sancho, que era seu líder, e seguiram seu caminho. Dom Pedro Fernandez de Albarracin, Dom Rodrigo Lizana e Dom Blasco de Alagón, estavam com Dom Fernando, e fizeram dele seu líder ${ }^{38}$.

Sabemos que o contexto que conhecemos como período feudal caracterizouse principalmente pela dispersão do poder. De posse desta informação e analisando a passagem acima, Jaime I novamente revelou-se como um rei feudal, uma vez que reinava sobre bandos e partidas, grupos que lutavam entre si e, em algumas vezes, até mesmo contra o próprio rei ${ }^{39}$.

Para nosso trabalho, identificamos este como o segundo momento na narrativa em que a imagem de Jaime aparece como um rei feudal: embora estivesse jurado, havia células de poder representadas por bandos e por partidas. Jaime era um rei em um contexto feudal, pois reinava não sobre um reino estabelecido, mas sim sobre homens, seus vassalos, e esses sobre seus bandos e partidas.

\footnotetext{
${ }^{35}$ Ganshof, F. L., Que é o Feudalismo? Lisboa: Publicações Europa-América, s/d., p. 112-113.

${ }^{36}$ Llibre dels Fets del Rei En Jaume, op. cit., caps. 15, 21, 26 e 27, nota 8.

37 Llibre dels Fets del Rei En Jaume, op. cit., cap. 20, nota 8.

${ }^{38}$ Llibre dels Fets del Rei En Jaume, op. cit., cap. 12, nota 8.

${ }^{39}$ Llibre dels Fets del Rei En Jaume, op. cit., caps. 22 e 24, nota 8.
} 


\subsection{Um rei contra seu vassalo: Jaime I contra Dom Pedro Ahones}

Para ser um rei feudal, Jaime devia reinar sobre os feudais, tentando sempre exercer sua legitimidade sobre os mesmos. Desse modo, para falarmos de Jaime I como um rei feudal, a guisa de exemplo examinaremos a relação de poder entre Jaime I e um de seus vassalos conhecido como Dom Pedro Ahones (?1226), um nobre aragonês.

Recordemos: já identificamos dois momentos em que Jaime fora caracterizado em sua narrativa como rei feudal. O primeiro durante sua consagração e o segundo quando bandos e partidas disputavam entre si o poder do reino quando o rei ainda estava no castelo de Monzón. O terceiro momento seria sua relação com Dom Pedro Ahones.

Como iniciou a relação entre Jaime I e Dom Pedro Ahones? Quais foram os momentos que o rei recordou seu vassalo em suas memórias? Como o rei recordou a relação com seu vassalo em sua narrativa? Encontraremos esta resposta no trecho onde Dom Pedro Ahones apareceu pela primeira vez no Livro dos Feitos pertencendo à partida do tio de Jaime I, Dom Sancho (c. ?-1223), o qual não comparecera à cerimônia de juramento em Lérida. Devemos lembrar que esta era uma forma de união comum àquela época, onde alguns cavaleiros seguiam a um senhor e este seguia a outro, até mesmo a um rei ${ }^{40}$.

Mais adiante Jaime I narrou o episódio do seqüestro de Dom Lope de Albero e a tomada dos castelos de Albero e de Lizana realizada pelo rei juntamente com seus guerreiros ${ }^{41}$, fato que demonstra que a guerra era um motor político muito utilizado pela realeza ${ }^{42}$. Aqui Dom Pedro Ahones, juntamente com seu bando, uniu-se a Jaime para auxiliá-lo. Desse modo observamos que em um primeiro momento Ahones estava unido a outro senhor e contra Jaime; depois, liderava sua própria partida a favor de Jaime. Este era um típico comportamento dos homens daquela sociedade, onde a mentalidade feudal traduzia-se por solidariedades verticais e horizontais num juramento de superiores e inferiores ${ }^{43}$.

Um terceiro momento que Jaime recordou Dom Pedro Ahones em suas memórias foi quando comentou sobre o casamento de seu vassalo, demonstrando, dessa forma, um grande poder de recordação, fato muito característico dos medievais ${ }^{44}$. Inclusive em outra passagem, o rei elogiou o conde ao afirmar que «com exceção de Dom Pedro Ahones, seu irmão, Dom Pelegrino, e Dom Guilherme de Poyo, os outros nos serviam tão mal e tão falsamente quanto podiam (...).» ${ }^{45}$ Além disso, é bem possível que Ahones participara do casamento e da consagração de Jaime como cavaleiro, uma vez que, até este momento da narrativa, não houvera nenhuma intriga entre o rei e o vassalo ${ }^{46}$.

40 Llibre dels Fets del Rei En Jaume, op. cit., cap. 12, nota 8.

41 Llibre dels Fets del Rei En Jaume, op. cit., cap. 15, nota 8.

${ }^{42}$ Loyn, H. R., Dicionário da Idade Média. Rio de Janeiro: Jorge Zahar, 1997, p. 312.

${ }^{43}$ Le Goff, Jacques, A civilização do Ocidente medieval. v. 1. Lisboa: Estampa, 1995, p. 124.

${ }^{44}$ Geary, Patrick. Memória. In: Le Goff, Jacques. \& Schmitt, Jean-Claude (Coords.). Dicionário Temático do Ocidente Medieval. v. 2. São Paulo: Edusc, 2002, p. 167-181.

${ }^{45}$ Llibre dels Fets del Rei En Jaume, op. cit., cap. 16, nota 8.

46 Llibre dels Fets del Rei En Jaume, op. cit., caps. 17, 18 e 19, nota 8. 
Adiante, Jaime I destacou o rompimento de amizade entre Dom Nuno Sanchez e Dom Guilherme de Montcada, nobres do reino de Aragão. Este episódio ocorreu devido a uma discussão entre Dom Nuno Sanchez e Dom Guilherme de Cervelhó por causa de um falcão. Nesse momento, Dom Pedro Ahones foi solicitado a estabelecer, juntamente com Dom Fernando, um laço de vassalagem com Dom Nuno, pois este não mantinha mais laços vassálicos com Dom Guilherme de Cervelhó e com Dom Guilherme de Montcada ${ }^{47}$. Isso demonstra que o jogo político no sistema feudal era permitido tanto pelo contrato de vassalagem quanto pela pluralidade de compromissos dos vassalos ${ }^{48}$.

Cabe ainda destacar a relação de parentesco presente no texto e exposta por Jaime: preocupado com Dom Nuno, o rei afirmou que «pesavam muito as palavras que ele nos dizia por este motivo: nós teríamos como nossa a sua desonra, tão forte era o parentesco que havia entre nós e ele» ${ }^{49}$. Segundo Anita Guerreau-Jalabert, o parentesco formulava-se como um conjunto de relações socialmente definidas e construídas ${ }^{50}$, e no caso da passagem acima observamos que o mesmo acontecia entre Jaime e seus cavaleiros. Em suma, o Livro de Jaime I nos revela que os homens de guerra possuíam um entrelaçamento de solidariedades entre si, assim como os guerreiros da batalha de Bouvines, em 1214: laços de família, laços complementares de vassalagem e laços de vizinhança ${ }^{51}$.

Na tomada dos castelos e das torres próximas a Cervelhó, Dom Pedro Ahones estava novamente ao lado de Jaime. Entretanto, nesse momento da narrativa, Dom Guilherme de Montcada estabeleceu um pacto com Dom Fernando e com Dom Pedro Ahones. Assim, quando Jaime se deslocava para a cidade de Alagón, os cavaleiros de Dom Guilherme de Montcada chegaram com Dom Pedro Ahones e Dom Fernando e invadiram a cidade de Alagón com o consentimento de Dom Nuno e Dom Pedro Ahones. Curiosamente, Jaime acusou de traição somente a Ahones ${ }^{52}$. Isso ficou claro na queixa que o rei faz à rainha Dona Leonor:

Saibais que todos os cavaleiros que vieram com Dom Fernando, com Dom Guilherme de Montcada e com Dom Pedro Ahones entraram e que os temos aqui em Alagón ${ }^{53}$.

Em seguida, o Livro dos Feitos apresenta o discurso dos traidores, os quais se arrependeram e aceitaram a idéia de retornarem a ser vassalos do rei. Então convidaram Jaime para entrar em Saragoça, pois eles estavam «preparados para fazer por vós o que se faz a um senhor.» ${ }^{54}$ Mas era uma cilada: quando chegou a

${ }^{47}$ Llibre dels Fets del Rei En Jaume, op. cit., cap. 20, nota 8.

${ }^{48}$ Le Goff, Jacques, op. cit., p. 127, nota 43.

49 Llibre dels Fets del Rei En Jaume, op. cit., cap. 20, nota 8.

${ }^{50}$ Guerreau-Jalabert, Anita. Parentesco. In: Le Goff, Jacques. \& Schmitt, Jean-Claude (Coords.). Dicionário Temático do Ocidente Medieval. v. 2. São Paulo: Edusc, 2002, p. 321-336.

${ }^{51}$ Duby, Georges, O Domingo de Bouvines. 27 de Julho de 1214. Rio de Janeiro: Paz e Terra, 1993 , p. 45.

${ }_{52}$ Llibre dels Fets del Rei En Jaume, op. cit., cap. 21, nota 8.

${ }^{53}$ Llibre dels Fets del Rei En Jaume, op. cit., cap. 21, nota 8.

${ }^{54}$ Llibre dels Fets del Rei En Jaume, op. cit., cap. 22, nota 8. 
noite, cerca de cem homens armados fizeram com que Jaime permanecesse isolado durante três semanas naquela cidade ${ }^{55}$.

Ao chegar a noite, disseram-nos que havia cerca de cem homens armados entre a nossa porta e uma portinhola que por onde se chegava ao muro da vila. Em seguida, convocaram G. Bohí e Pedro Sanz de Martel, que vieram à nossa casa, fizeram seus leitos e dormiram ali, onde as senhoras costumam dormir. A rainha, quando ouviu os homens armados que estavam do lado de fora e aqueles que tinham entrado na casa para dormir diante de nós, se pôs a chorar muito fortemente e nós, que estávamos com ela, a confortamos. E entrou diante de nós G. Bohí e Pedro Sanz de Martel, e G. Bohí disse à rainha: «Senhora» disse ele «não chorais, porque logo poderás se confortar, pois pelas lágrimas vertidas se perde a razão. Ademais, todas estas lágrimas retornarão em gozo, e vossa ira passará». A guarda de prontidão dia e noite diante de nós durou cerca de três semanas ${ }^{56}$.

Diante desta situação, percebe-se claramente que a intenção desses cavaleiros era eliminar a possibilidade de Jaime I exercer seu poder, sua autoridade. Isso levou o rei a romper o pacto com Dom Pedro Ahones. A partir de então, ele não mais seria seu vassalo.

Depois disso, chamamos Dom Pedro Ahones em um canto e lhe dissemos: Dom Pedro Ahones, temos lhe amado muito e lhe honrado por parte de Dom Artal de Alagón. E vós retribuís com essa desonra tão grande como a que estamos recebendo! Pois a partir de agora rompemos com vosso amor. Enquanto vivermos, não vos amaremos. Ele perguntou: Por qual razão? Nós respondemos: Por que vedes nossa desonra e nosso dano, e se não estivésseis ausente não teríamos recebido essa desonra e este dano, pois poderíeis desfazê-lo, mas não o desfizestes. Ele então discutiu conosco sobre isso, disse que não nos desonrava, nem nos causava dano com seu comportamento, e não deu importância às nossas palavras ${ }^{57}$.

Jaime estava em Saragoça e acabara de receber o juramento da parte de Dom Fernando, de Dom Guilherme de Montcada e de Dom Pedro Ahones, os quais disseram que fariam as vontades de Jaime como se fizessem a um senhor. Entretanto, o rei ficou sitiado nesta vila, o que o deixou irritado com os homens que acabaram de jurar fidelidade à sua pessoa.

Ao analisarmos o trecho acima, percebemos que a reclamação de Jaime referia-se à falta de assistência por parte de seu vassalo, uma vez que necessitara de sua ajuda em uma situação de perigo. Como sabemos, um dos deveres dos vassalos era abster-se de causar dano ao seu senhor ${ }^{58}$. O vassalo devia o consilium, ou

55 Llibre dels Fets del Rei En Jaume, op. cit., cap. 22, nota 8.

${ }^{56}$ Llibre dels Fets del Rei En Jaume, op. cit., cap. 22, nota 8.

${ }^{57}$ Llibre dels Fets del Rei En Jaume, op. cit., cap. 22, nota 8.

${ }^{58}$ Como na carta que Fulbert de Chartres enviou ao duque da Aquitânia, Guilherme V: «Aquele que jura fidelidade a seu senhor deve ter sempre presente na memória estas seis palavras: 
conselho, que era a participação nas assembléias, e o auxilium, ou auxílio, que poderia ser tanto militar quanto financeiro. Além disso, estava obrigado a contribuir na administração das terras dos senhores, na justiça e no exercício senhorial ${ }^{59}$, desde que o senhor lhe dispensasse tratamento equivalente ${ }^{60}$.

Ao reclamar da falta de seu vassalo, Jaime indicou um comportamento contrário por parte do mesmo. O rei deixou bem claro que o amava, o honrava e mesmo assim ele «retribuía» com uma «desonra tão grande». Diante disso, a atitude de Jaime foi romper com a relação vassálica existente entre os dois, já que Dom Pedro Ahones conhecia suas obrigações como vassalo e não as cumpria, ausentando-se em um momento que o rei precisava de seu auxílio. Caso o senhor faltasse com suas obrigações, o vassalo podia desafiá-lo, ou seja, retirar a fé que depositou em seu senhor. Da mesma forma, caso o vassalo faltasse com seus compromissos, o senhor podia acusá-lo de felonia, ou seja, traição ${ }^{61}$.

Qual seria o motivo de Jaime recordar, logo no início de sua narrativa, todos estes problemas com seu vassalo? Refletimos: Jaime necessitava legitimar-se perante seus nobres e perante sua linhagem. Para isso, devia representar sua história construindo uma narrativa onde sua imagem fosse legitimada como um rei que exercia a autoridade sobre seus vassalos. Entretanto, observando atentamente a narrativa sobre a relação entre Jaime I e Dom Pedro Ahones, reconhecemos que Jaime não exercia a autoridade sobre seus vassalos e sim tentava estabelecer a mesma. Ao recordar em suas memórias a relação com Dom Pedro Ahones e estabelecê-las por escrito, compreendemos que o rei desejava que seus sucessores soubessem de suas tentativas para estabelecer sua autoridade perante seus vassalos, soubessem de sua busca pela auctoritas. Por isso, compreendemos que o rei descreveu sua narrativa de uma forma consciente e legitimadora, pois a cobrança feita por Jaime foi uma conseqüência da falta de auxílio de seu vassalo. Portanto, Jaime se representava como um rei feudal que buscava estabelecer sua autoridade sobre aqueles que lhe deviam fidelidade. Diante dessas informações, a relação entre Jaime I e Dom Pedro Ahones representa um ponto chave na leitura do Livro dos Feitos: ela reproduz toda a dificuldade encontrada pelo

incólume, seguro, honesto, útil, fácil e possível. Incólume, na medida em que não deve causar prejuízos corpóreos ao seu senhor; seguro, para que não traia os seus segredos ou as armas pelas quais ele possa manter [-se] em segurança; honesto, para que não enfraqueça os seus direitos de justiça ou de matérias que pertençam à sua honra; útil, para que não cause prejuízo às suas possessões; fácil ou possível, visto que não deverá tornar difícil ao seu senhor o bem que ele facilmente poderia fazer, nem tornar impossível o que para ele seria possível. Todavia, se é justo que o (vassalo) fiel evite estas injúrias, não será só por isto que merece benefício; porque não é suficiente abster-se do mal, a menos que faça também o que é bom. Portanto, deverá em adição conceder fielmente conselho e ajuda ao seu senhor nas seis coisas acima mencionadas, se deseja ser considerado merecedor do seu benefício e digno de confiança na fidelidade que jurou.» De fulbert de Chartres ao Duque de Aquitânia Guilherme V (1020). Pedrero-Sánchez, Maria Guadalupe. História da Idade Média: textos e testemunhas. São Paulo: Unesp, 2000, p. 24.

${ }^{59}$ Le Goff, Jacques, op. cit., p. 125-126, nota 43.

${ }^{60}$ Duby, Georges, Castelos: poder e soberania. Revista História Viva, São Paulo, ano 2, n. ${ }^{\circ}$ 18, p. 60-64, 2005.

${ }^{61}$ Le Goff, Jacques, op. cit., p. 125-126, nota 43. 
monarca para estabelecer-se como rei de fato, para estabelecer sua auctoritas sobre seus súditos logo no começo do seu reinado. Podemos imaginar que, dessa forma, Jaime reproduziu e reencenou todos os problemas, todo o fio condutor de sua relação com Dom Pedro Ahones em suas memórias como uma forma de demonstrar para seus sucessores as dificuldades pelas quais passara e que, mesmo apesar disso, reinou; ou seja, representou por meio de suas memórias o que desejava que os sucessores soubessem sobre sua vida.

Seguindo o itinerário do rei, de Saragoça ele foi para Tortosa e depois se dirigiu para Horta. Nesse local, ordenou que todos os ricos-homens que possuíam feudos por ele fossem ao seu encontro na cidade de Teruel, pois desejava, a partir desta localidade, atacar a cidade de Valência ${ }^{62}$. Porém, no dia marcado, chegaram apenas alguns de seus vassalos, como Dom Blasco de Alagón, Dom Artal de Luna e Dom Ato de Foces. Tal fato demonstra a dificuldade do rei em estabelecer a autoridade sobre seus súditos, pois, na maioria das vezes, um senhor não obtinha obediência de seus vassalos caso não mantivesse com os mesmos uma relação pessoal ${ }^{63}$. Isso foi uma característica do reinado de Jaime, pois, pela documentação disponível, vemos que o rei realizou uma intensa locomoção entre as suas terras, mesmo que com o passar dos anos este deslocamento tenha diminuído ${ }^{64}$.

Como o rei estava com poucos cavaleiros, o sítio de Valência não se realizou, e como conseqüência Jaime estabeleceu uma trégua com o rei muçulmano seid Abu Seid, na qual este pagaria uma quinta parte das rendas de Valência e de Múrcia ${ }^{65}$. Em troca, Jaime se limitava a não atacar a cidade valenciana. Estas exigências financeiras e defensivas, que aconteceram durante o processo de Reconquista da Península Ibérica, foram realizadas tanto de muçulmanos para cristãos quanto de cristãos para muçulmanos, e favoreceram o rápido enriquecimento das partes credoras. Estes procedimentos ocorreram entre os séculos XI, XII e $\mathrm{XIII}^{66}$, em um momento que a guerra era a forma mais rápida de enriquecimento ${ }^{67}$.

Ao retornar para Aragão, Jaime encontrou Dom Pedro Ahones com aproximadamente cinqüenta ou sessenta cavaleiros armados. Ao saber que este tinha intenção de «entrar na terra dos mouros, ele e seu irmão, o bispo de Saragoça», Jaime o convenceu a retornar, e os dois se dirigiram para Burbáguena, onde se encontravam alguns nobres ${ }^{68}$.

${ }^{62}$ Llibre dels Fets del Rei En Jaume, op. cit., cap. 25, nota 8.

${ }^{63}$ Duby, Georges. Los Feudales. In: Obras selectas de Georges Duby. México: Fondo de cultura econômica, 1999, p. 103.

${ }^{64}$ Utrilla Utrilla, Juan F. Jaime I (1213-1276): aspectos más sobresalientes de un reinado. In: Colón Domènech, Germá i Martínez Romero, Tomàs (Eds.). El rei Jaume I: fets, actes i paraules. Barcelona: Publicacions de l'Abadia de Montserrat, 2008, p. 53-73.

${ }^{65}$ Llibre dels Fets del Rei En Jaume, op. cit., cap. 25, nota 8.

${ }^{66}$ Navarro, Francesc, Historia Universal. La expansión musulmana. Madrid: Salvat, s/d, p. 437, 479 .

${ }^{67}$ Franco Júnior, Hilário, Peregrinos, monges e guerreiros: feudo-clericalismo e religiosidade em Castela medieval. São Paulo: Hucitec, 1990, p. 40.

${ }^{68}$ Llibre dels Fets del Rei En Jaume, op. cit., cap. 25, nota 8. 
Este é um claro exemplo da ineficiência do poder do rei no início de seu reinado. Depois de ter sido preso pelos próprios vassalos em Saragoça ${ }^{69}$, humilhação irreparável para um rei, agora suas ordens não eram acatadas. E pior: eram contrariadas, pois a intenção de Ahones era atacar as terras valencianas depois que o rei estabelecera uma trégua com o líder muçulmano ${ }^{70}$.

Quando chegaram à cidade de Burbáguena, Jaime cobrou de Ahones a sua falta por não ir à cidade de Teruel, de onde partiriam para fazer uma cavalgada ${ }^{71}$ às terras dos mouros. E ainda disse que por isso,

seid Abu Seid nos disse que daria as quintas de Valência e de Múrcia para que tivéssemos uma trégua com ele, e as tomamos. Por isso, vos rogamos, Dom Pedro Ahones, e vos ordenamos que tenhais estas tréguas e não as rompais ${ }^{72}$.

O rei demonstrou preocupação com a possibilidade de seu vassalo romper uma trégua, fato ilícito que atingiria a moral de Jaime ${ }^{73}$. Assim, contrariando o seu suserano, Ahones respondeu que pelo custo da reconciliação que fizera com seu irmão não acataria o pedido de seu senhor. Mas o rei voltou a insistir:

Dom Pedro Ahones, grande erro nos dissestes, pois fizemos aquela trégua por vossa falta, já que não viestes no dia que dissemos. E agora dizeis que não deixareis esta ida por nossa ordem. Olhais o que fazeis, pois vós vireis contra o nosso senhorio, coisa que não esperamos. Assim, desejamos saber se vós deixareis de fazer isso apesar dos nossos pedidos e das nossas ordens ${ }^{74}$.

Jaime insistiu três vezes com Dom Pedro e em todas elas foi mal sucedido. Essa insistência de Jaime mostra que o rei dispensava atenção e cuidado a Ahones, além de se preocupar com o possível rompimento da trégua que fizera com Abu Seid. É interessante a passagem onde Jaime diz que «vós vireis contra o nosso senhorio». Teria Jaime perdoado a primeira falha de Ahones, quando este o manteve sitiado em Saragoça? Isso não fica claro na leitura do Livro. Porém, vendo que o conde não mudava de idéia, o rei sentenciou: «já que desejais romper uma coisa tão preciosa como essa, dizemos que desejamos prendê-lo. $\rangle^{75}$ Assim, depois de aconselhar, o rei passou a ordenar, a última forma de poder do vínculo feudal ${ }^{76}$; porém, novamente, Ahones não acatou.

${ }^{69}$ Llibre dels Fets del Rei En Jaume, op. cit., cap. 22, nota 8.

70 Villacañas, José Luis, op. cit., p. 104-105, nota 7.

${ }^{71}$ As cavalgadas eram aventuras violentas que ocorriam a cada primavera, realizadas pelos cavaleiros. Costa, Ricardo da. A violência da cavalaria medieval e o processo civilizador dos oratores. Dimensões - Revista de História da Ufes. Vitória, Universidade Federal do Espírito Santo, Centro de Ciências Humanas e Naturais, n. ${ }^{\circ}$ 13, p. 174-186, 2001.

${ }^{72}$ Llibre dels Fets del Rei En Jaume, op. cit., cap. 25.

${ }^{73}$ Gauvard, Claude. Justiça e Paz. In: Le Goff, Jacques. \& Schmitt, Jean-Claude (Coords.). Dicionário Temático do Ocidente Medieval. v. 2. São Paulo: Edusc, 2002, p. 55-62.

${ }^{74}$ Llibre dels Fets del Rei En Jaume, op. cit., cap. 25, nota 8.

75 Llibre dels Fets del Rei En Jaume, op. cit., cap. 25, nota 8.

76 Villacañas, José Luis., op. cit., p. 105, nota 7. 
Este foi o momento em que Jaime I e seu vassalo acusado de felonia ficaram frente a frente. Esta parte da narrativa merece uma atenção especial, principalmente por que ela irá desembocar na morte de Dom Pedro Ahones. Os cavaleiros que acompanhavam o rei o desampararam e somente observaram-no lutar contra seu vassalo ${ }^{77}$. Esta atitude não deve ser entendida pejorativamente, como se os cavaleiros do rei o tivessem abandonado: ao reconstruir esta cena em suas memórias, Jaime provavelmente tinha a intenção de demonstrar que a sua coragem e a sua força cavaleiresca estavam à altura da sua honra.

Possivelmente Jaime recordara este confronto contra seu vassalo para ilustrar os primeiros anos de seu reinado: agitados, difíceis e desanimadores. Porém, ao refletir sobre seus feitos, compreendemos que o rei destacara esta relação entre senhor e vassalo não somente para representar as dificuldades pelas quais passara, mas também para demonstrar sua busca pela legitimidade e autoridade que o tornaria um rei respeitado perante seus súditos. Dessa forma, a relação entre Jaime I e Dom Pedro Ahones, inserida nas memórias do rei, deve ser compreendida no sentido de que Jaime almejava que todos soubessem que diante de tal situação agia com nobreza, destreza e convicção de seus atos. Não esqueçamos: o rei, ao ditar seus feitos, refletia sobre seu passado e desejava que todos o conhecessem. Nesse sentido, compreendemos que o mesmo narrou esta relação com o intuito de que soubessem sobre suas dificuldades em reinar. Inserida nos momentos iniciais do reinado de Jaime I, a relação com Dom Pedro Ahones significa muito mais que uma simples luta entre senhor e vassalo: ela indica as dificuldades iniciais de Jaime em se estabelecer como rei, em conseguir sua auctoritas diante de seus vassalos.

Retomando a narrativa, Jaime e Ahones entraram em luta corporal, mas o $\mathrm{Li}$ vro dos Feitos nos apresenta que Ahones fora auxiliado pelos seus cavaleiros, os quais impediram Jaime de prender seu vassalo ${ }^{78}$. Após isso, Ahones e seus cavaleiros fugiram e rapidamente e foram perseguidos por Jaime, Dom Ato, Dom Blasco e Dom Artal ${ }^{79}$.

A partir desse ponto o que decidiu este episódio foram as condições de estratégia de guerra até o momento da trágica morte de Dom Pedro Ahones. Afirmamos anteriormente que o fato de não ter sido obedecido por Dom Pedro Ahones demonstra a ineficiência do poder de Jaime sobre seus vassalos no início de seu reinado. Porém, em nossa análise, todo este episódio também representa um momento que Jaime adquiriu consciência sobre seu papel como rei: um rei devia reinar a qualquer custo. Desse modo, conforme a narrativa progride, a imagem de Jaime como rei feudal se fortalece. Devido às circunstâncias em que viveu, Jaime I adquiriu experiência e com o tempo vivenciou sua imagem de rei dentro de um ambiente feudal. Um jovem rei feudal, destacamos. Como um esboço, a realeza de Jaime se aperfeiçoou aos poucos, formou-se com o passar dos anos.

${ }^{77}$ Llibre dels Fets del Rei En Jaume, op. cit., cap. 26, nota 8.

${ }^{78}$ Llibre dels Fets del Rei En Jaume, op. cit., cap. 26, nota 8.

${ }^{79}$ Llibre dels Fets del Rei En Jaume, op. cit., cap. 26, nota 8. 
Estes primeiros anos do reinado de Jaime têm um significado especial: receber o reino como um patrimônio familiar não significava que o rei exerceria o poder de fato; este deveria ser conquistado. Desde que saíra do castelo de Monzón e que estivera entre os seus naturais nada estava garantido. Assim, ao refletir sobre o seu passado e colocá-lo por escrito, Jaime o elaborou com a intenção de legitimar-se perante seus vassalos opositores e perante sua linhagem no intuito de superar seus antecessores; além disso, o rei sabia que dependia única e exclusivamente de si mesmo para efetuar o exercício da realeza ${ }^{80}$.

Diante da busca pela sua legitimidade, Jaime narrou em suas memórias a morte de seu vassalo. Esta, pela análise da narrativa, foi uma consequiência da vontade do rei em impor sua vontade, impor seu poder sobre seus vassalos, buscando, dessa forma, arregimentar seus nobres ao seu redor e assim fortalecer seu poder. Nestes primeiros anos de reinado, a imagem que representou de si mesmo em relação ao contexto de seu reino era um a de um rei que lutava para exercer seu poder e impor sua autoridade.

Assim, pouco a pouco, conforme o desenrolar dos acontecimentos, a maturidade de Jaime I surge na narrativa do Livro dos Feitos. Aos poucos sua legitimidade adquire contornos, apresentando uma grande diferença em comparação aos primeiros anos de seu reinado. Jaime vivia em um mundo de transformações; seu mundo ainda era, mesmo que com algumas mudanças, o mundo feudal. Naquele ambiente o rei necessitava dos conselhos dos nobres, principalmente um rei como Jaime, novo e sem experiência naquele cotidiano.

Até mesmo porque, por várias vezes no decorrer da fonte, o próprio rei admitiu que ainda não tinha idade para dar conselhos. No total, antes do trecho referente à conquista de Maiorca, seu primeiro grande feito de armas, Jaime afirmou três vezes que não possuía senso para dar conselho, que não sabia guiar a terra e que, por isso, era necessário que os nobres o aconselhassem. Na última afirmação, o rei tinha não mais que catorze anos ${ }^{81}$.

Porém, até quando o rei necessitaria de conselho? Vimos que Jaime afirmou isso por três vezes nos capítulos referentes aos primeiros anos de sua vida. Diante dessa pergunta, o capítulo 29 do Livro dos Feitos torna-se importante para ser analisado. Mesmo sem esta experiência, neste momento da narrativa o rei recusou um conselho. Esta recusa seria uma aquisição de consciência ou imaturidade? Vejamos o motivo.

\subsection{Um rei consciente e que não necessita de conselhos?}

Identificamos dois momentos cruciais nos quais Jaime aparece na narrativa do Livro dos Feitos com certa maturidade em comparação com momentos anteriores. Após a morte de Dom Pedro Ahones, em 1226, ocorreu uma sublevação da nobreza aragonesa, a qual formou uma coalizão contra o rei ${ }^{82}$. Quando estava

\footnotetext{
80 Villacañas, José Luis., op. cit., p. 106, nota 7.

81 Llibre dels Fets del Rei En Jaume, op. cit., caps. 15, 16 e 21, nota 8.

82 Utrilla Utrilla, Juan F., op. cit., p. 53-73, nota 64.
} 
na localidade de Lascellas, Jaime fora aconselhado por seu vassalo, Dom Pedro Pomar, a se refugiar em um monte «muito forte», ou seja, difícil de ser conquistado. Porém, Jaime não aceitou este conselho:

Dom Pedro Pomar, nós somos rei de Aragão por nosso direito, e estes que vêm contra nós são nossos naturais e fazem o que não devem, pois vem combater contra nós. Nós temos o direito, eles têm o erro. Por isso, Deus nos ajudará, e nós não deixaremos a vila a não ser morto; e mesmo com tudo isso nós os venceremos. Assim, dessa vez não tomaremos vosso conselho ${ }^{83}$.

$\mathrm{O}$ rei, que tanto necessitava de conselho, que tanto precisava de ajuda durante os primeiros anos de seu reinado agora recusava o auxílio. Ou melhor, devido à sua posição, recusava algo que não devia fazer: o fazia porque amadurecia e ganhava experiência naquele cotidiano de guerra.

Desse modo, o que nos importa não é a recusa do conselho e sim o motivo $d a$ dispensa. Ao analisar este trecho por este caminho observamos que o motivo da recusa está relacionado ao amadurecimento de Jaime. Ele sabia que era rei por direito e aqueles que o combatiam estavam no erro, pois combatiam contra o rei, contra seu senhor. Em um ambiente feudal, este confronto ocorria porque havia um choque entre diferentes concepções de poder: a de Jaime e de seus conselheiros diretos, e a dos membros da aristocracia que lhe eram contrários ${ }^{84}$.

Para a mentalidade da época, estar ao lado do direito era importante para o desenvolvimento dos acontecimentos terrestres. Como uma crença geral, Deus não abandonava quem era justo e seguramente Jaime pensava assim. A morte de Dom Pedro Ahones, o senhor mais importante de Aragão naquela época, fato que gerou uma revolta por parte de alguns nobres, não fora por um motivo fortuito: este nobre estava contra o senhorio do rei ${ }^{85}$.

Por pensar conscientemente no que era correto, Jaime acreditava que Deus o ajudaria, pois tinha como verdade que Ele sempre apoiava o lado certo nas batalhas, típica concepção dos medievais ${ }^{86}$. Nas próprias palavras de Ferran Soldevila, Jaime «deveria, de pouco a pouco, pelo próprio esforço e pela dura aprendizagem da vida, cobrar autoridade diante dos soberbos ricos-homens e barões ${ }^{87}$.

O Livro dos Feitos é uma narração das ações de um rei situado em um momento específico do reino de Aragão. Jaime se encontrava em uma «encruzilhada» da história da Europa, vivia a experiência de um «homem de fronteira», algumas vezes cavaleiro, outras conquistador, mas sempre muito consciente do que fazia ${ }^{88}$.

${ }^{83}$ Llibre dels Fets del Rei En Jaume, op. cit., cap. 29, nota 8.

${ }^{84}$ Utrilla Utrilla, Juan F, op. cit., p. 53-73, nota 64.

85 Villacañas, José Luis, op. cit., p. 107-108, nota 7.

${ }^{86}$ Duby, Georges, op. cit., p. 157, nota 51.

${ }^{87}$ Soldevila, Ferran, Els grans reis del segle XIII. Jaume I i Pere el Gran. Barcelona: Vicens-Vives, 1965, p. 15 (A tradução é nossa).

${ }^{88}$ Ruiz-Domènec, José Enrique, Salvar la imagen del caballero. In: Jaime I, Rey y Caballero. Los arneses y la cultura caballeresca en el siglo XIII. València: Laimprenta, CG, 2008, p. 91-95. 
Assim, ao ditar sua vida, Jaime desejou que seus feitos fossem relembrados por todos. Seu Livro representa suas memórias, suas recordações sobre seu reinado. E é por meio de suas recordações que encontramos o segundo momento em que esta fonte nos apresenta uma mudança de personalidade de Jaime, não totalmente concreta, mas com uma notável diferença: trata-se do seu primeiro discurso na narrativa. Nesta mensagem o rei manifestou toda sua insatisfação com parte da nobreza aragonesa e com tudo que acontecera até então. Era aproximadamente abril de 1227 :

Barões, cremos que sabeis e deveis saber que nós somos de longo tempo vosso senhor natural; que conosco Aragão teve quatorze reis, e quanto mais distante é a natureza entre nós e vós, mais aproximação deve existir, pois ao se estender o parentesco, por essa extensão a natureza se estreita. Nunca lhes fizemos mal, nem falamos mal, pelo contrário, temos em nosso coração a intenção de amá-los e honrá-los, e lhes faremos ter todos os bons costumes que temos tido de nossa linhagem, e lhes daremos ainda melhores, se não tiveres aqueles que são bons. Por isso, maravilhamo-nos muito em ter que nos proteger de vós, que não possamos entrar nas cidades que Deus nos deu e que nosso pai nos deixou, e nos pesa muito que haja guerra entre nós e vós. Assim, rogamos e ordenamos que isso não aconteça, pois nos pesa muito, e podeis perceber isso, pois vim somente para estar entre vós, pois confio em vós e em vosso amor, e vos tenho guardados com amor no coraçãa ${ }^{89}$.

Quando narrou seus feitos o próprio rei confessou que em alguns momentos não era capaz de dar conselho, pois não estava preparado para governar seu reino. Porém, compreendemos que em seu primeiro discurso Jaime construiu uma personalidade diferente, principalmente pela influência do meio em que vivia: guerras constantes, disputas, um universo militar onde se exigia maturidade de qualquer líder.

Narrando seus feitos muito tempo depois do acontecimento dos mesmos, Jaime formulou-se na narrativa do Livro dos Feitos como um rei consciente de sua autoridade e que estava em condições de explicá-la aos seus nobres. Da mesma forma que Villacañas e Belenguer, acreditamos que este primeiro discurso de Jaime representa um momento muito importante na narrativa, pois aqui o mesmo está ciente de seu papel de monarca e da sua intenção de se legitimar diante de seus nobres e de sua linhagem. Seguramente não ocorrera o mesmo em Saragoça, onde as lágrimas de sua primeira esposa, Leonor (1202-1244), caíram ao saber que estava presa nesta cidade. Agora, ao contrário do que acontecera em Saragoça, o rei se libertava sozinho, com a sua própria força, valor e decisão $0^{90}$.

Até aqui percebemos que há um encadeamento dos feitos contados por Jaime. Aos poucos o descobrimos, compreendemos suas palavras relacionadas ao contexto em que viveu e conseqüentemente a tentativa de estabelecer sua autoridade surge vagarosamente depois de uma densa interpretação. De pouco a

${ }^{89}$ Llibre dels Fets del Rei En Jaume, op. cit., cap. 31, nota 8.

90 Villacañas, José Luis, op. cit., p. 110, nota 7; BELENGUER, Ernest., op. cit., p. 71-72, nota 21. 
pouco desvendamos as pistas que Jaime nos deixou por escrito e que o tornam, no seu entendimento, um rei legitimado. Desse modo, pretendemos aqui reconstituir uma possível imagem que Jaime desejava que todos que lessem seu Livro tivessem de suas ações como rei. Em outras palavras, o que aspiramos é estabelecer uma aproximação com a visão de Jaime sobre seus primeiros anos como monarca. Porém, não compartilhamos da idéia de que as fontes oferecem um acesso imediato à realidade: tomamos como pressuposto que elas se apresentam como espelhos deformantes ${ }^{91}$. Em nosso caso, a deformação do Livro dos Feitos provêm do fato de que fora composto muitos anos depois dos acontecimentos. Isso, juntamente com a idéia de que o mesmo se trata tanto de uma tentativa de legitimação efetuada por Jaime diante de parte de sua nobreza opositora quanto de uma intenção de superar os antecessores da casa dos condes de Barcelona ${ }^{92}$, faz com que tenhamos que nos deter sobre a forma que Jaime construiu sua narrativa e, conseqüentemente, dar uma especial atenção aos detalhes narrados pelo rei.

A cada capítulo, o Livro dos Feitos apresenta um rei que adquire consciência do seu papel como conde de Barcelona na formação do reino de Aragão. Afirmamos isso tomando as próprias palavras de Jaime, pois, quando refletiu sobre a sua história e afirmou que era o décimo quarto rei de Aragão recordou não apenas a naturalidade de sua linhagem, mas também construiu uma ponte com o passado e tornou este passado presente em suas palavras, tentando reforçar, desse modo, sua autoridade sobre seus vassalos.

Quando recordou que era conde de Barcelona e rei de Aragão, Jaime retomou e reforçou a continuidade dinástica, e destacou que por um longo tempo a casa de Barcelona reinava naquelas terras. Dessa forma, no decorrer de seus feitos, Jaime se estabelecia de uma maneira estável perante os seus vassalos; ainda não possuía a auctoritas, como explicamos anteriormente. A única coisa que possuía verdadeiramente era o direito de sua herança ${ }^{93}$; por isso o utilizou em seu primeiro discurso.

Para compreendermos melhor a utilização do passado por parte do rei, passado revivido em suas memórias, dividimos seu discurso em quatro partes, onde o rei:

1) explicou a natureza da relação entre ele e seus nobres, obviamente a natureza feudal;

2) recordou a intenção e o dever dele para com os barões;

3) ficou surpreso em ter que se proteger de seus nobres e não poder reinar como um rei e;

4) rogou e ordenou que aquilo não acontecesse novamente.

Ao invocar a relação de parentesco e destacar que a mesma existia há um longo tempo (lonch temps), Jaime identificou as bases sobre as quais seu poder

${ }^{91}$ Ginzburg, Carlo. Introdução. In: Relações de força: História, retórica, prova. São Paulo: Companhia das Letras, 2002, p. 44-45.

${ }_{92}$ Vianna, Luciano J., op. cit., nota 2.

93 Villacañas, José Luis, op. cit., p. 59, nota 7. 
estava constituído. Na verdade, com a intenção de acabar com a «anarquia» que existia em seu reino, Jaime exaltou a natureza feudal para aproximar-se de seus vassalos e submetê-los ao seu comando, o que faria com que eles o reconhecessem como rei.

Em seguida destacou seus deveres como rei feudal, onde teria por seus vassalos «a intenção de amá-los e honrá-los». Cumprindo a obrigação de um senhor, Jaime faria todo o bem pelos seus naturais. Vale notar que, sem compreender o motivo de ser atacado por pessoas que lhe deviam fidelidade, Jaime primeiro lembrou seu dever, ou seja, honrar seus homens e «amá-los», e somente no final do discurso destacou a reciprocidade dessa relação: «pois confio em vós e em vosso amor».

A terceira parte do discurso é representada pela insatisfação do rei com os acontecimentos ocorridos. São três queixas: 1) o fato de que ele tinha que se proteger de seus próprios vassalos; 2) de que não podia entrar nas cidades que seu pai, Pedro, o Católico, deixara e 3) que lamentava muito pela guerra que existia entre ele e seus vassalos.

Nesse estado de coisas, compreendemos que não havia possibilidades para Jaime exercer sua função de rei, um rei que teria que governar seu reino, comandar seus vassalos e mobilizar seus exércitos que lhe deviam obediência. Por isso é que discursou com a intenção de acabar com tudo que acontecia. Todos estes problemas com a nobreza aragonesa se acabariam momentaneamente com o estabelecimento da Paz de Alcalá em $1227^{94}$. Este pacto representou um período de transição no contexto da Coroa de Aragão, relacionado tanto com o fim da adolescência do rei quanto com o fim dos problemas com a nobreza. A partir de então, surgira um bom e favorável momento para que o rei empreendesse suas conquistas ${ }^{95}$. Nessa ocasião, pela análise da narrativa, sua maturidade já é bem notável se a compararmos com momentos anteriores, onde o rei não tinha capacidade para aconselhar ${ }^{96}$.

Por último, no final do discurso rogou e ordenou para que aquilo não mais acontecesse, uma vez que ele confiava em seus vassalos e os tinha em uma relação de reciprocidade, guardados em seu coração. Jaime já estaria cansado de tanta desordem? É o que parece. Mas também já apresentava certa maturidade e certa competência para exercer seu ofício: ao menos é essa a mensagem que compreendemos que o rei ofereceu em suas reflexões sobre aqueles momentos de sua vida.

Ofício não apenas como um rei feudal, mas também como um rei cavaleiro, um rei que durante sua infância passara por momentos de preparação cavaleiresca e que agora, juntamente com a consciência adquirida, realizaria o seu primeiro grande feito de armas, a conquista de Maiorca. Porém, para exercer

${ }^{94}$ González Antón, L. La revuelta de la nobleza aragonesa contra Jaime I en 1224/1227. Homenaje a Don José María Lacarra en su jubilación del profesorado. Zaragoza, 1977, p. 143163.

\footnotetext{
95 Soldevila, Ferran, op. cit., p. 18, nota 87.

96 Ver nota 81.
} 
esta função guerreira inerente à sua pessoa e que lhe serviria como legitimação ${ }^{97}$, um rei devia se preparar militarmente. Desse modo, agora, analisaremos o caso de Jaime e sua preparação cavaleiresca durante seus primeiros anos.

\section{A FORMAÇÃO DE UM REI CAVALEIRO}

Mas, o que era a cavalaria? Antes do século XII a palavra «cavalaria» indicava as qualidades do cavaleiro ou uma ação digna de um cavaleiro. A partir da segunda metade do século XII, essa palavra passou a designar o conjunto dos cavaleiros em um sentido profissional. Por fim, já no século XIV, no decorrer da Guerra dos Cem Anos (1337-1453), ela passou a definir confrarias destinadas a concentrar os adeptos de um grupo ou de uma convicção ${ }^{98}$. Na verdade, falar de cavalaria é falar ao mesmo tempo de uma forma de viver e de pensar que foi reflexo de uma sociedade ${ }^{99}$.

Em nosso caso, especificamente nos interessa o contexto da cavalaria no século XIII. Neste momento ela estava inserida em uma ordem social ${ }^{100}$, fazia parte do cotidiano e estava integrada em uma mentalidade que se formara há bastante tempo. Fazia parte de um conjunto e era responsável pela harmonia do mes$\mathrm{mo}^{101}$. Ela se legitimava ao realizar sua tarefa defensiva e era necessária para que a ordem social se mantivesse harmônica. Ela possuía dois sentidos, um militar e outro social: era um grupo profissional e também um título nobiliário ${ }^{102}$.

Os homens que participavam desta ordem necessitavam de muitos atributos. Por exemplo, deviam ser honrados, pois tal característica fazia com que o guerreiro estivesse adornado de uma áurea purificadora que o legitimava em suas ações cavaleirescas. Além disso, na busca por um cavaleiro ideal, a maioria dos escritores da época afirmavam que ser honrado era indispensável a um cavaleiro, uma vez que este seria regido por um código de regras e de normas que o levariam a ter atitudes devidas e bem direcionadas para sua função ${ }^{103}$.

${ }^{97}$ Le Goff, Jacques. Le roi dans l'Occident Médiéval. In: Le Goff. Héros du Moyen Âge, le Saint et le Roi. Paris: Gallimard, 2004, p. 1086.

${ }_{98}$ Levi, Giovanni e Schmitt, Jean-Claude, História dos Jovens 1. Da Antiguidade à Era Moderna. São Paulo: Companhia das Letras, 1996, p. 148.

${ }_{99}$ Flori, Jean, Cavalaria. In: Le Goff, Jacques. \& Schmitt, Jean-Claude (Coords.). Dicionário Temático do Ocidente Medieval. v. 1. São Paulo: Edusc, 2002, p. 185-199.

${ }^{100}$ Iogna-Prat, Dominique. Ordem(ns). In: Le Goff, Jacques \& Schmitt, Jean-Claude (Coords.). Dicionário Temático do Ocidente Medieval. v. 2. São Paulo: Edusc, 2002, p. 305-319.

${ }_{101}$ Segundo Emilio Mitre Fernández, os estamentos/estados/condições/ordens estão inseridos em um esquema onde cada um deve desempenhar sua função no grupo a que pertence para que a harmonia permaneça. Isso porque o pensamento medieval considerava o mundo como uma integração harmoniosa dos homens com Deus, com a natureza e com eles mesmos. Fernández, Emilio Mitre. História del Cristianismo. v. 2. El mundo medieval. Madrid: Trotta, 2004, p. 98.

${ }_{102}$ Flori, Jean, op. cit., p. 185-199, nota 99.

103 Maíz Chacón, J., «La argumentación filosófica del caballero medieval. El modelo e ideal luliano em el Libre del Orde de Cavaleria». Costa, Ricardo da. Tôrres, Moisés Romanazzi e Zierer, Adriana. Mirabilia. Revista Eletrônica de História Antiga e Medieval, n. ${ }^{\circ}$ 05, 2005. Disponível em: http://www.revistamirabilia.com/Numeros/Num5/art4.htm. Acesso em 05 de Julho de 2009. 
Também deviam ser corajosos para realizarem suas tarefas. Nessa época, nada melhor a um guerreiro que demonstrar vontade de vencer nas lutas que participava. Esforço tanto para si quanto para Deus, pois os guerreiros que participaram do que conhecemos modernamente como Cruzadas e Reconquista estavam não somente preocupados em conquistar honras e poderio, mas também em serem reconhecidos como guerreiros que lutavam para defender sua crença contra os infiéis ${ }^{104}$.

Além disso, deviam ter rendas para se sustentarem. Assim, falar de cavalaria é falar de homens que possuíam rendimentos, homens que eram sustentados pelo trabalho de uma imensa parte da população medieval, os camponeses. Ao serem sustentados por estes, os cavaleiros tinham tempo para se dedicarem integralmente às suas ações cavaleirescas e se tornarem especialistas na arte da guerra. No século XIII, trabalhar com as mãos não era uma atividade nobre, e os integrantes da cavalaria, instituição ligada à nobreza, desprezavam o trabalho desta atividade produtiva e valorizavam a largueza ${ }^{105}$.

No caso de Jaime I, como podemos encontrar as pistas sobre sua formação como cavaleiro no Livro dos Feitos? Com base nas informações acima, agora investigaremos a formação de Jaime I como rei cavaleiro durante seus primeiros anos de vida sob a responsabilidade de outros personagens.

\subsection{A formação de Jaime I como rei cavaleiro}

Ofício de cavaleiro é manter e defender a santa fé católica pela qual Deus, o Pai, enviou seu Filho para encarnar na virgem gloriosa Nossa Senhora Santa Maria, e para a fé ser honrada e multiplicada, sofreu neste mundo muitos trabalhos e muitas afrontas e grande morte. Daí que, assim como Nosso Senhor elegeu clérigos para manter a Santa Fé com escrituras e com provocações necessárias, pregando aquela aos infiéis com tão grande caridade que até a morte foi por eles desejada, assim o Deus da glória elegeu cavaleiros que por força das armas vençam e submetam os infiéis que cada dia pugnam em destruir a Santa Igreja. Onde, por isso, Deus honrou neste mundo e no outro tais cavaleiros que são mantenedores e defensores do ofício de Deus e da fé pela qual nos havemos de salvar ${ }^{106}$.

Uma das características mais relevantes do Livro dos Feitos é a exaltação do mundo da guerra, além das virtudes cavaleirescas como a proeza e a coragem ${ }^{107}$; fato

${ }^{104}$ Cardini, Franco. Guerra e Cruzada. In: Le Goff, Jacques. \& Schmitt, Jean-Claude (Coords.). Dicionário Temático do Ocidente Medieval. v. 1. São Paulo: Edusc, 2002, p. 473-487.

105 Zierer, Adriana M. S. Paraíso, Escatologia e Messianismo em Portugal à época de D. João I. 2004. Tese de Doutorado. Programa de Pós-Graduação em História, Universidade Federal Fluminense, Niterói, 2004.

${ }^{106}$ Ramon Llull, O Livro da Ordem de Cavalaria (Tradução, revisão e notas Ricardo da Costa). São Paulo: Editora Giordano, 2000, p. 23.

107 Porredon, Romi, «Introducció». In: Jaume I. La conquista de Mallorca del Llibre dels fets. Barcelona: La Magrana, 1997, p. 13. 
normal, uma vez que esta obra é fruto das reflexões de um rei que, por meio das guerras e conquistas, duplicou a extensão dos reinos que recebeu em sua infância. Além disso, as próprias palavras de Jaime no Livro dos Feitos contêm uma vontade de ser reconhecido e contemplado como um rei cavaleiro $^{108}$. Não podemos esquecer que a educação cavaleiresca de Jaime I ocorrera ainda durante sua infância. Quais foram estes períodos? Como podemos identificá-los no Livro dos Feitos?

Pela leitura do Livro dos Feitos identificamos três momentos importantes para a formação de Jaime como um rei cavaleiro, onde o mesmo passara por uma aprendizagem inicial no mundo das armas ${ }^{109}$. Em um primeiro momento, por volta de 1211, Jaime permaneceu sob os cuidados de Simon de Montfort em Carcassone, quando este ainda mantinha boas relações com o seu pai, Pedro, o Católico, e antes da batalha de Muret, que opôs estes dois cavaleiros e terminou com a morte deste último:

Passado o tempo de nosso nascimento, Dom Simon de Montfort, que tinha as terras de Carcassonne, de Bèziers e de Toulouse, as quais ganhou do rei de França, quis ter o amor de nosso pai e pediu-lhe que nos entregasse a ele para ele nos educar. E ele confiou tanto nele e em seu amor que nos entregou a ele para nos nutriir ${ }^{110}$.

O pacto que o rei nos apresentou se realizara em janeiro de 1211; Jaime tinha então três anos ${ }^{111}$. Ainda que a narrativa não mencione, de acordo com este pacto Jaime se casaria com a filha de Simon de Montfort, Amicia. Enquanto este matrimônio não se realizasse, o rei seria educado na corte do nobre francês ${ }^{112}$. Seria neste espaço turbulento que Jaime viveria os primeiros anos em um ambiente cavaleiresco.

A batalha de Muret ocorreria dois anos mais tarde; porém, os primeiros sinais da união entre Inocêncio III e o rei Felipe Augusto (1165-1223) (o primeiro interessado na paz no Languedoc e o segundo na expansão territorial para este mesmo local) já eram notados antes mesmo de Jaime permanecer sob os cuidados do conde Simon de Montfort ${ }^{113}$. Assim, os primeiros anos de vida de Jaime I (entre 1211 e 1214) seriam vivenciados em torno da preparação para a efetiva cruzada contra os cátaros e os seus senhores occitanos, declarada por Inocêncio III desde $1208^{114}$. Este perdera o seu legado pontifício, Pedro de Castelnou (?-

108 Villacañas, José Luis, op. cit., p. 23, nota 7.

109 Vianna, Luciano J., «A cavalaria medieval e a formação inicial de Jaime I como rei cavaleiro no Llibre dels Fets (c. 1252-1274)». Costa, Ricardo da. Tôrres, Moisés Romanazzi e Zierer, Adriana. Mirabilia. Revista Eletrônica de História Antiga e Medieval, n. ${ }^{\circ}$ 08, 2008. Disponível em: http://www.revistamirabilia.com/Numeros/Num8/numero8_10.htm. Acesso em 07 de Julho de 2009.

${ }^{110}$ Llibre dels Fets del Rei En Jaume, op. cit., cap. 8, nota 8.

111 Tourtoulon, Ch., Don Jaime I el Conquistador, rey de Aragón. v. 1. Valencia: Frederico Doménech, 1874, p. 88-89.

112 Soldevila, Ferran, op. cit., p. 12, nota 87.

113 Villacañas, José Luis, op. cit., p. 35-39, nota 7.

114 Alvira Cabrer, Martín, Muret 1213. La batalla decisiva de la cruzada contra los cátaros. Barcelona: Ariel, 2008, p. 34. 
1208), no mesmo ano que o rei Jaime nascera. Como consequiência, resolveu responder esta violência com violência. Por isso prometia que:

Diante de tal ameaça concedemos a remissão dos pecados, para que sem demora remediais a tão grandes perigos. Esforçai-vos em pacificar estas populações em nome de Deus, da paz e do amor. Aplicai-vos em destruir a heresia por todos os meios que Deus os inspire. Com mais firmeza ainda que com os sarracenos, porque são mais perigosos, combateis os hereges com mãos poderosas e braços estendidos ${ }^{115}$.

Trata-se de uma expansão da Cruzada contra os hereges occitanos. Uma guerra declarada em nome de Deus e, nas palavras de Inocêncio, autorizada por Ele. Fora neste meio que Jaime crescera e permanecera na fortaleza de Carcassone entre os anos de 1211-1214. Coincidentemente, o conde Simon fez desta inexpugnável fortificação o seu centro de operações durante a formação do teatro da guerra contra os cátaros, até o momento que todos os personagens estivessem presentes para a grande cena final, aquela que decidiu o futuro da política dos condes de Barcelona e reis de Aragão: Muret. Podemos imaginar, pois é bem provável, que Jaime permanecera neste ambiente, embora não o recorde com detalhes em seu Livro.

Assim, dois anos antes da batalha decisiva onde seu pai encontrara a morte, Jaime já estava presente nas mãos de Simon de Montfort e com ele permaneceria por três anos. De acordo com o tratado feito entre Pedro, o Católico e o conde Simon, Jaime se casaria com a filha deste em um momento oportuno. Podemos imaginar então que, neste momento, Jaime fora introduzido no ambiente da cavalaria: uma educação inicial, como a de qualquer outra criança com aproximadamente sua idade. Mais importante que isso, este momento inicial da vida do rei seria marcado por um ambiente de guerra, pois, desde 1208 o papa Inocêncio já declarara a luta contra os cátaros ${ }^{116}$.

Um ano depois de Muret, Jaime retornou aos seus naturais por intermédio de Inocêncio III. A partir desse momento, logo após o juramento nas Cortes Gerais de Lérida, o rei novamente retomou seus aprendizados na arte cavaleiresca desta vez em Monzón, pois, pelas palavras do rei «estivemos dois anos e meio entregue a um tenente» ${ }^{117}$. Palavras significativas, pois relacionam a infância do rei, pela primeira vez, diretamente com o âmbito militar.

O limiar da vida. Era a idade correta para aprender a ser cavaleiro, aprender o que significava esse ofício, entender a mentalidade cavaleiresca. Ao repetir um velho provérbio carolíngio, Marc Bloch nos contou que isso era fato: «aquele que, sem saber montar a cavalo, ficou na escola até aos doze anos, só serve para ser padre.» ${ }^{118}$ Pode soar estranho às nossas mentes contemporâneas, mas tal atitude era corrente naquela sociedade. Foi provavelmente durante estes anos que

\footnotetext{
115 Alvira Cabrer, Martín, op. cit., p. 36, nota 114 (A tradução é nossa).

116 Alvira Cabrer, Martín, op . cit., p. 33-34, nota 114.

117 Llibre dels Fets del Rei En Jaume, op. cit., cap. 11, nota 8.

118 Bloch, Marc. A sociedade feudal. Lisboa: Edições 70, 2001, p. 308.
} 
Jaime recebeu suas primeiras instruções na arte cavaleiresca. Sua iniciação nas armas e a aprendizagem do significado da cavalaria se processaram durante os anos iniciais de sua vida, ainda que de uma forma inusitada.

Assim, este foi o segundo momento da formação de Jaime como cavaleiro onde permaneceu sob a tutela dos Templários. Após sair dos cuidados de Simon de Montfort, o rei afirmou que seus nobres:

acordaram quando estiveram em Catalunha quem nos educaria, e todos concordaram que quem nos educaria seria o mestre do Templo em Monzón. O nome daquele mestre era Dom Guilherme de Montredon, natural de Osona e mestre do Templo em Aragão e Catalunha ${ }^{119}$.

Segundo cenário da infância militar de Jaime: o castelo de Monzón, fortaleza templária ideal para a formação de um cruzado ${ }^{120}$. Embora sua regra não permitisse, os templários aceitavam crianças para serem educadas. $\mathrm{O}$ aceite ocorria porque essas crianças eram filhas de benfeitores da Ordem. Por exemplo, Guilherme VI de Montpelier (1102-1162) ${ }^{121}$, ao fazer seu testamento, legou a herança ao primogênito e destinou o secundogênito para ser educado pelos irmãos do Templo ${ }^{122}$.

Assim, podemos conjecturar que, devido a sua educação templária, Jaime fora iniciado definitivamente no ofício de cavaleiro, o qual, nas palavras de Ramon Llull, ajudaria a «manter e defender a santa fé católica.» ${ }^{123}$ Foi então entre os cavaleiros do Templo que o rei iniciou sua aprendizagem no mundo das armas, a qual devia começar desde muito cedo. Além disso, provavelmente fora entre estes mesmos cavaleiros que Jaime aprendeu suas primeiras competências gráficas, como ler e escrever um pouco de latim, base de qualquer educação naquela época ${ }^{124}$.

Mas não podemos esquecer outro fator que auxiliou na formação de Jaime como rei cavaleiro: o contexto em que nasceu e viveu, representado pela reconquista dos territórios cristãos ocupados pelos sarracenos. Provavelmente isso influenciou na construção da noção do dever de cavaleiro na concepção de Jaime, uma vez que, a partir da conquista de Maiorca, seu contato com os sarracenos, com os infiéis, seria cada vez maior. Dessa forma, seu aprendizado cavaleiresco ocorreu ao longo de sua vida e Maiorca foi seu primeiro grande feito de armas a serviço de Deus. Grande feito de armas que destacou no Livro dos Feitos como legitimação diante de seus nobres e também como continuador da linhagem dos condes de Barcelona ${ }^{125}$.

119 Llibre dels Fets del Rei En Jaume, op. cit., cap. 10, nota 8.

${ }_{120}$ Villacañas, José Luis, op. cit., p. 77, nota 7.

${ }^{121}$ Senhor de Montpelier entre os anos de 1121 e 1149.

122 Demurger, Alain, Os cavaleiros de Cristo. As ordens militares na Idade Média (sécs. XIXVI). Rio de Janeiro: Jorge Zahar, 2002, p. 84-85.

${ }^{123}$ Ramon Llull, op. cit., p. 23, nota 106.

${ }^{124}$ Cingolani, Stefano Maria, Historia y mito del rey Jaime I de Aragón. Barcelona: Edicions 62, 2008, p. 83-84.

125 Vianna, Luciano J., op. cit., nota 2. 
A defesa da Santa Fé, função cavaleiresca, já fora destacada desde os tempos de São Bernardo de Claraval (1090-1154), que escreveu o sermão De laude novae militae ${ }^{126}$. Este tratado foi uma das fontes do desenvolvimento do ideal cavaleiresco ${ }^{127}$, principalmente porque explicava a divisão entre militia e malitia ${ }^{128}$. $\mathrm{Na}$ visão do monge de Claraval, estes soldados eram considerados instrumentos de Deus para castigar os malfeitores e defender os justos ${ }^{129}$.

A vida do rei em Monzón provavelmente seria regada pela disciplina ascética dos cavaleiros templários, os quais o protegiam de possíveis atentados. Foi durante esse período que o rei passou por uma educação muito mais que militar: passara por uma educação religiosa, marcada pelo ódio aos infiéis, pelo incentivo à conquista das terras pertencentes ao Islã e pelo estímulo de retomar o Santo Sepulcro ${ }^{130}$. Todas estas características estão bem presentes em suas memórias recordadas no Livro dos Feitos.

Este período da vida do rei nos é apresentado de uma forma muito conturbada, principalmente nos seus primeiros anos. Como o próprio rei afirmou em seu Livro, partidas lutavam entre si para tomar terras e obterem o controle do reino, momento em que parte da nobreza aproveitou para expor suas reivindicações ${ }^{131}$. Tanto que, logo após sua saída do castelo de Monzón, Jaime narrou seu início na utilização das armas:

Nós saímos de Monzón ao alvorecer. E quando chegamos à ponte, a comitiva que nos esperava nos disse que o conde Dom Sancho estava em Selgua com todo o seu poder, e que nos combateria. Nós tínhamos então somente nove anos e, por causa do temor da batalha na qual pensávamos entrar, um cavaleiro nos emprestou uma loriga para que nos vestíssemos. Esse foi nosso princípio nas primeiras armas que vestimos ${ }^{132}$.

Eis o terceiro e mais importante momento que Jaime recebeu uma educação cavaleiresca: a ocasião em que voltou para seus naturais, sua primeira entrada no reino de Aragão. A partir desse momento, Jaime se dividiu entre aventuras (cavalgadas) e realidades (problemas de seu reino). Foi dentro desse contexto que ele se formou como cavaleiro, que lutou e adquiriu experiência nas armas, que se

${ }^{126}$ Rodríguez-Picavea Matilla, Enrique, Los monjes guerreiros en los reinos hispánicos. as órdenes militares en la Península Ibérica durante la Edad Media. Madrid: La esfera de los libros, 2008, p. 25-30.

${ }_{127}$ Previté-Orton, C. W., Historia del mundo en la Edad Media. Ramon Sopena: Barcelona, 1995, p. 1261.

128 São Bernardo distinguiu, desta forma, a cavalaria do século da cavalaria de Deus: aqueles que lutavam contra os preceitos cristãos e aqueles que lutavam a favor dos mesmos. Grabois, Areyh. Militia and Malitia: The Bernardine Vision of Chivalry. De Re Militari: The Society for Medieval Military History. Disponível em: http://www.deremilitari.org/resources/articles/grabois.htm. Acesso em 20 de Fevereiro de 2009.

129 Silva, Pedro, História e Mistérios dos Templários. Rio de Janeiro: Ediouro, 2001, p. 14.

${ }_{130}$ Belenguer, Ernest, op. cit., p. 47-48, nota 21.

131 Rodríguez-Picavea Matilla, Enrique, op. cit., p. 185, nota 126.

132 Llibre dels Fets del Rei En Jaume, op. cit., cap. 14, nota 8. 
preparou para a conquista de Maiorca; a qual acreditava que conquistara com a ajuda de Deus, legitimando-se, dessa forma, diante de sua nobreza e como continuador de sua linhagem ${ }^{133}$.

Depois de toda preparação, todo cavaleiro devia ter sua cavalaria, ou seja, o dia oficial em que se tornava cavaleiro. Assim como todo cavaleiro, Jaime passou pela sua, um dia inesquecível na vida de qualquer aspirante à ordem ${ }^{134} \mathrm{e}$ que o próprio rei não esqueceu de destacar em suas memórias:

Nossa cavalaria aconteceu em Santa Maria de Horta, em Tarragona. Ouvida a missa do Espírito Santo, cingimos a espada que tomamos do altar. Podíamos ter então doze anos completos, entrando no décimo terceiro ano ${ }^{135}$.

Tornar-se cavaleiro era obter um reconhecimento, uma colocação hierárquica na ordem social ${ }^{136}$. Para ser sagrado cavaleiro havia um local: uma igreja. No caso de Jaime, toda cerimônia ocorreu em um âmbito religioso, cristianizado. Este ambiente o abençoava e fazia com que a consagração se tornasse transcendente, pois não era um cavaleiro que seria nomeado, mas um cavaleiro de Cristo, que iria compor o exército cristão contra os infiéis. Ao ser nomeado na casa de Deus, Jaime presenciou que devia protegê-la a todo custo.

Havia uma preparação: escutava-se uma missa. Era um momento em que Cristo se fazia presente através da comunhão e onde o cavaleiro podia eximir-se dos seus pecados. Ele devia estar purificado, já que serviria de exemplo tanto para seus iguais quanto para os que iria defender.

Desse modo, vemos que a cavalaria de Jaime aconteceu bem depois que ele iniciara sua preparação. Provavelmente por volta dos seis anos iniciou seus treinamentos e por volta dos doze ou treze, de acordo com as informações do Livro dos Feitos, tornou-se cavaleiro. Um bom tempo para adquirir certa aprendizagem nas armas. Aprendizagem, pois a experiência apenas viria durante a sua vida.

$$
\text { * * * }
$$

Cremos que estas três facetas sobre os primeiros anos de Jaime I, um rei natural, um rei feudal e um rei cavaleiro foram importantes para a formação do rei como um Conquistador. Por meio delas observamos as três «direções» que o Livro dos Feitos nos indica para uma melhor compreensão da construção da imagem de Jaime I: um rei natural, confirmado pelo poder dos simbolismos terrestres e celestes; um rei feudal, que lutou diante dos problemas que surgiam, chegando ao ponto de causar a morte de seu próprio vassalo; e um rei cavaleiro, que se preparou militarmente desde cedo, passando por tutelas preparatórias para forjar um verdadeiro Conquistador. Ainda que sejam desenvolvidas no começo da narrativa, estas facetas também surgem em outros momentos do Livro dos Feitos. Vejamos um exemplo.

\footnotetext{
133 Vianna, Luciano J., op. cit., nota 2.

134 Para o assunto, ver Duby, Georges, El siglo de los caballeros. Madrid: Alianza, 1995.

135 Llibre dels Fets del Rei En Jaume, op. cit., cap. 19, nota 8.

136 Villacañas, José Luis, op. cit., p. 94, nota 7.
} 
Durante a conquista de Maiorca, especificamente nas primeiras horas do dia 12 de setembro de 1229 , antes da batalha de Portopí1 ${ }^{137}$, o então bispo de Barcelona, Berenguer de Palou (1212-1241), pronunciou um discurso onde destacou as três facetas de Jaime I, as quais encontramos nos primeiros capítulos do Livro dos Feitos. Naquela empresa, Jaime cumpria uma de suas funções como rei: guerrear. Durante esta empresa Jaime participou de muitos enfrentamentos entre cristãos e muçulmanos. Um deles foi a batalha de Portopí.

Para um cavaleiro medieval, os sinais celestes fariam a diferença durante a batalha, já que o mesmo acreditava que estas confirmações o ajudariam a reconhecer se os céus concordavam com suas intenções. Para isso, preparavam-se antecipadamente com os ritos religiosos para combater em nome de Deus. O mesmo aconteceu na batalha de Portopí: o dia começou com as preparações transcendentais representadas pelo sermão do bispo de Barcelona, Berenguer de Palou:

Barões, agora não é hora de fazer um longo sermão, pois a ocasião não nos permite. Este feito em que nosso senhor rei e vós estais, é obra de Deus, não nossa. Logo, deveis fazer esta conta: aqueles que neste feito receberem a morte, a receberão de Nosso Senhor, e terão o Paraíso, onde terão a glória perdurável por todos os tempos; aqueles que viverem terão honra e valor em suas vidas e bom fim em suas mortes. Assim, barões, confortai-vos com Deus, porque o rei, vosso senhor, nós e vós, desejamos destruir aqueles que renegam o nome de Jesus Cristo. Todos os homens devem pensar, e podem, que Deus e Sua Mãe não se separarão de nós hoje, pelo contrário, nos darão a vitória. Portanto, deveis ter bom coração, pois assim vencerão tudo, já que a batalha deve ser hoje. Confortai-vos e alegrai-vos bem, pois vamos com um senhor bom e natural, e Deus, que está acima dele e de nós, ajudar-nos-ál ${ }^{138}$.

Em seu livro, Villacañas afirma que a intenção do bispo de Barcelona era recordar que aquela empresa estava inserida no movimento de Cruzada e aqueles nobres que o escutavam e que participariam da mesma receberiam a glória perdurável no Paraíso ${ }^{139}$. Porém, se observamos atentamente as palavras de Berenguer de Palou, cuja militante homilia fora pronunciada «em tom de enaltecimento dos ânimos» ${ }^{140}$, o significado das mesmas vão muito mais além e se referem não somente ao contexto da época e ao momento em específico, mas também a Jaime I, sua relação com seus vassalos e sua legitimidade perante os mesmos.

Recordando as palavras do bispo de Barcelona, Jaime destacou em seu Livro cinco questões importantes que se relacionam com o momento em questão: 1) as

137 Vianna, Luciano J., «Ah, Santa Maria, ajudais aos nossos, pois parece que o encontro já começou: a batalha de Portopí na conquista de Maiorca (1229)». SINAIS, Revista Eletrônica. Ciências Sociais. Vitória: CCHN, UFES, Edição n. 04, v.1, Dezembro. 2008. p. 56-70.

${ }_{138}$ Llibre dels Fets del Rei En Jaume, op. cit., cap. 62, nota 8.

139 Villacañas, José Luis, op. cit., p. 143, nota 7.

140 Arández, Alvaro Santamaría, Determinantes de la conquista de Baleares. Mayurqa: revista del Departament de Ciències Històriques i Teoria de les Arts, Mallorca, n. ${ }^{\circ}$ 8, p. 65-133, 1972. 
indulgências; 2) a guerra contra os muçulmanos; 3) a relação dos céus com a vitória; 4) a moral cavaleiresca e; 5) a legitimidade de Jaime I perante os nobres. Todos estes fatores são importantes para se entender a conjuntura do momento e também a construção da autoridade de Jaime I.

$\mathrm{O}$ primeiro item refere-se à questão das indulgências. Os que batalhassem nesta empresa de Deus seriam recompensados, tanto os que morressem quanto os que sobrevivessem: estes teriam honra e valor e um bom fim nas mortes; aqueles receberiam a morte de Nosso Senhor e teriam o Paraíso. Tais benefícios eram atrativos para estes homens e motivavam muitos a se engajarem nestas lutas. Na verdade, os objetivos iniciais das Cruzadas eram ajudar aos cristãos do Oriente e libertar o túmulo de Cristo. Quando estes guerreiros participavam das Cruzadas, tinham como objetivo assegurar a salvação no outro mundo ${ }^{141}$. Em Maiorca não fora diferente: nesta passagem que o exército cristão fizera sob a liderança de Jaime, Berenguer de Palou recordara este ganho transcendental.

Para ganhar esta salvação deviam proteger a Cristo; no Oriente, deviam recuperar a Terra Santa; no Ocidente, especificamente na Península Ibérica, também foram autorizados a expulsar da terra os infiéis que a ocupavam. Assim, guerreavam em nome de Deus contra os muçulmanos. Observamos: trata-se do discurso de um bispo, um religioso, um homem ligado à Igreja. Este é um dos momentos da narrativa que fica clara a presença do ideal de Guerra Santa Cristã (bellum iustum) na passagem para Maiorca.

Seguindo as palavras pronunciadas por Berenguer de Palou, encontramos outro fator importante que influenciou naqueles momentos anteriores à batalha: a recordação de que aquela empresa possuía uma ligação com um propósito divino. Desse modo, a vitória na batalha de Portopí não seria conquistada e sim dada por Deus aos seus escolhidos. Diante disso, o bispo de Barcelona afirmou que todos deveriam pensar que Deus e Sua Mãe estariam com eles e que lhes dariam a vitória contra os infiéis.

Isso porque estamos diante de um mundo diferente, no qual a crença dos cavaleiros era composta por uma fé intensa e sentida com autenticidade, uma fé vigorosa que inspirava e se impregnava de Providencialismo. Uma fé eficaz, voltada para a crença e para a alimentação espiritual ${ }^{142}$.

Como eram cavaleiros, aqueles nobres deviam ter bom coração, característica muito importante para um cavaleiro medieval. Este fator está ligado à moral cavaleiresca, muito presente nos livros de cavalaria que eram escritos naquela época. É certo que durante as Cruzadas a Igreja preocupou-se com a ética da cavalaria $^{143}$. Além disso, entre os séculos $\mathrm{V}$ e XV a guerra e atividade das armas passaram do monopólio aristocrático para o âmbito do serviço público. Mesmo com essa mudança a condição e a dignidade inerentes aos cavaleiros exigiam

${ }^{141}$ Vauchez, André, A Espiritualidade na Idade Média ocidental. Rio de Janeiro: Jorge Zahar, 1995 , p. $62,91$.

${ }_{142}$ Arández, Alvaro Santamaría, op. cit., p. 65-133, 1972, nota 140.

${ }^{143}$ Loyn, H. R., op. cit., p. 83, nota 42. 
que a utilização da força fosse realizada moderadamente e sempre fosse colocada a serviço de Deus e dos pobres ${ }^{144}$.

Distantes daquele mundo por mais de oito séculos, não é fácil para nós, homens do século XXI compreender aqueles sentimentos destacados por Jaime I no discurso do bispo sob a ótica dessacralizada representada pelo nosso tempo ${ }^{145}$. Para isso é necessário que nós, que estamos à frente da Idade Média, permaneçamos de frente para a mesma para observamos seu mundo, diferente do nosso, com um olhar sem pré-conceitos. Assim, poderemos compreender ou ao menos nos aproximar dos significados, das palavras e dos gestos pelos quais os medievais se expressavam.

O último ponto importante a ser destacado nas palavras que Jaime colocou no discurso do bispo, e que está relacionado com o tema deste artigo, é em relação à imagem do rei perante os nobres: «Confortai-vos e alegrai-vos bem, pois vamos com um senhor bom e natural (...)» ${ }^{146}$. Berenguer de Palou foi mais além: ao destacar essas qualidades de Jaime I, o discurso do bispo enfatizou e fortaleceu a imagem do rei perante seus vassalos e reforçou a naturalidade da linhagem que existia entre o rei e os mesmos (um rei natural), destacou a liderança de Jaime (um rei feudal) e afirmou que juntamente com o rei combateriam em Portopí (um rei cavaleiro).

\section{CONCLUSÃO}

Os capítulos do Livro dos Feitos localizados antes da conquista de Maiorca representam, em nossa opinião, um importante conjunto de informações sobre os primeiros anos de Jaime. Porém, antes de se tornar o Conquistador, cognome que em nossa hipótese pode ser legado ao rei principalmente depois da conquista de Maiorca, identificamos três prováveis facetas do rei que serviram para fortalecer sua imagem perante seus nobres, principalmente perante os problemas que encontrou em seu reino. Diante dessa afirmação, os anos que começaram a retratar Jaime I como rei representam também, de certa forma, uma formação importante na vida do rei menino, não sendo, logo, capítulos «confusos e mal recordados», como o afirmara o Lluís Nicolau d'Olwer ${ }^{147}$.

Em nossa opinião as três construções são complementárias para a compreensão da construção da imagem de Jaime I, o Conquistador, visto que as mesmas estarão presentes durante toda a narrativa do Livro dos Feitos. Porém, o mais importante é que elas aparecem antes do primeiro grande feito de armas do rei, ou seja, a conquista de Maiorca, que em nosso entendimento fora um «laboratório» onde o rei praticou grande parte daquilo que aprendera durante seus primeiros anos e uma conquista que o tornou conhecido por todo o «mundo» da-

${ }^{144}$ Cardini, Franco, op. cit., p. 473-487, nota 104.

145 Arández, Alvaro Santamaría, op. cit., p. 65-133, nota 140.

146 Llibre dels Fets del Rei En Jaume, op. cit., cap. 62, nota 8.

147 Nicolau D’Olwer, Lluís, «La Crónica del Conqueridor i els seus problemas». Estudis Universitaris Catalans, n. ${ }^{\circ} 11,1926$, p. 79-88. 
quela época. Além disso, como vimos, o discurso do bispo de Barcelona, que fora colocado na boca do mesmo por Jaime I, deixou claro a importância das três facetas do rei para aquele momento. Desse modo, antes de ser um Conquistador, Jaime fora um rei natural, um rei feudal e um rei cavaleiro, construções importantes para a sua gestação como o Conquistador.

\section{REFERÊNCIAS BIBLIOGRÁFICAS}

\section{Fontes primárias}

De Fulbert de Chartres ao Duque de Aquitânia Guilherme V (1020). Pedrero-SánCHEZ, Maria Guadalupe, História da Idade Média: textos e testemunhas. São Paulo: Unesp, 2000.

Gestes dels comtes de Barcelona i Reis d'Aragó (A cura de Stefano Maria Cingolani). València: Universitat de València/Monuments d'Història de la Corona d'Aragó, 2008.

Jaime I. Libro de los hechos (Introducción, traducción y notas de Julia Butiñá Jiménez). Madrid: Gredos, 2003.

Llibre dels Fets del Rei En Jaume. 2 vol. (A cura de Jordi Bruguera). Barcelona: Barcino, 1991.

RAMOn Llull. O Livro da Ordem de Cavalaria (Tradução, revisão e notas Ricardo da Costa). São Paulo: Editora Giordano, 2000.

\section{Fontes secundárias}

ALVIRA CABRER, Martín, Muret 1213. La batalla decisiva de la cruzada contra los cátaros. Barcelona: Ariel, 2008.

ARÁNDEZ, Alvaro Santamaría. Determinantes de la conquista de Baleares. Mayurqa: revista del Departament de Ciències Històriques i Teoria de les Arts, Mallorca, n. ${ }^{\circ} 8$, p. 65-133, 1972.

AURELL, Jaume. From genealogies to chronicles: the power of the form in medieval catalan historiography. Viator, Berkeley, n. ${ }^{\circ}$ 36, p. 235-264, 2005.

Belenguer, Ernest, Jaume I i el seu regnat. Lleida: Pagès Editors, 2007.

BLOCH, Marc, A sociedade feudal. Lisboa: Edições 70, 2001.

—, Os reis taumaturgos. São Paulo: Companhia das Letras, 1993.

CAPdeferro, Marcelo, Otra historia de Cataluña. Barcelona: Acervo, 1990.

CARDINI, Franco. Guerra e Cruzada. In: Le Goff, Jacques. \& SchmitT, Jean-Claude (Coords.), Dicionário Temático do Ocidente Medieval. v. 1. São Paulo: Edusc, 2002, p. 473-487.

CAWSEY, Suzanne F., Reialesa i propaganda. L'eloqüència reial i la Corona d'Aragó, c. 1200-1450. València: Publicacions Universitat de València, 2008.

Cingolani, Stefano Maria, Historia y mito del rey Jaime I de Aragón. Barcelona: Edicions 62, 2008. 
—, La memòria dels reis, Les Quatre Grans Cròniques i la historiografia catalana, des del segle X fins al XIV. Barcelona: Base, 2008.

- Seguir les vestígies dels antecessors. Llinatge, reialesa i historiografia a Catalunya de Ramon Berenguer IV a Pere II (1131-1285). Anuario de Estudios Medievales, Barcelona, Consejo Superior de Investigaciones Científicas, v. 1, n. ${ }^{\circ}$ 36, p. 201-240, 2006.

Costa, Ricardo da, A violência da cavalaria medieval e o processo civilizador dos oratores. Dimensões - Revista de História da Ufes. Vitória, Universidade Federal do Espírito Santo, Centro de Ciências Humanas e Naturais, n. ${ }^{\circ}$ 13, p. 174-186, 2001.

Demurger, Alain, Os cavaleiros de Cristo. As ordens militares na Idade Média (sécs. XI-XVI). Rio de Janeiro: Jorge Zahar, 2002.

Diccionari catalã-valencià-balear. Disponível em: http://dcvb.iecat.net. Acesso em 12 de Março de 2008.

Duby, Georges, Castelos: poder e soberania. Revista História Viva, São Paulo, ano 2, n. ${ }^{\circ}$ 18, p. 60-64, 2005.

—, El siglo de los caballeros. Madrid: Alianza, 1995.

—, Los Feudales. In: Obras selectas de Georges Duby. México: Fondo de cultura econômica, 1999.

—, O Domingo de Bouvines. 27 de Julho de 1214. Rio de Janeiro: Paz e Terra, 1993.

FERnANDEs, Raúl Cesar Gouveia. Reflexões sobre o Estudo da Idade Média. LAUAND, Luiz Jean (coord.). Revista VIDETUR, n. ${ }^{\circ}$ 6, 1999. Disponível em: http://www.hottopos.com.br/videtur6/raul.htm. Acesso em 16 de Fevereiro de 2008.

FERNÁNDEZ, Emilio Mitre, História del Cristianismo. v. 2. El mundo medieval. Madrid: Trotta, 2004.

Flori, Jean. Cavalaria. In: Le Goff, Jacques. \& SchmitT, Jean-Claude (Coords.), Dicionário Temático do Ocidente Medieval. v. 1. São Paulo: Edusc, 2002, p. 185-199.

Franco JúNIOR, Hilário. A Idade Média: nascimento do Ocidente. São Paulo: Brasiliense, 2001.

—, Peregrinos, monges e guerreiros: feudo-clericalismo e religiosidade em Castela medieval. São Paulo: Hucitec, 1990.

Ganshof, F. L., Que é o Feudalismo? Lisboa: Publicações Europa-América, s/d.

Gauvard, Claude. Justiça e Paz. In: Le Goff, Jacques. \& Schmitt, Jean-Claude (Coords.), Dicionário Temático do Ocidente Medieval. v. 2. São Paulo: Edusc, 2002, p. 55-62.

Geary, Patrick. Memória. In: Le Goff, Jacques. \& Schmitt, Jean-Claude (Coords.), Dicionário Temático do Ocidente Medieval. v. 2. São Paulo: Edusc, 2002, p. 167-181.

GINZBURG, Carlo, Introdução. In: Relações de força: História, retórica, prova. São Paulo: Companhia das Letras, 2002.

GonZÁlEz ANTón, L., La revuelta de la nobleza aragonesa contra Jaime I en 1224/1227. Homenaje a Don José María Lacarra en su jubilación del profesorado. Zaragoza, 1977.

GraboIs, Areyh. Militia and Malitia: The Bernardine Vision of Chivalry, De Re Militari: The Society for Medieval Military History. Disponível em: 
http://www.deremilitari.org/resources/articles/grabois.htm. Acesso em 20 de Fevereiro de 2009.

Guerreau-Jalabert, Anita. Parentesco. In: Le Goff, Jacques. \& Schmitt, Jean-Claude (Coords.), Dicionário Temático do Ocidente Medieval. v. 2. São Paulo: Edusc, 2002, p. 321-336.

HAuf, Albert G., «Més sobre la intencionalitat dels textos historiogràfics catalans medievals». Medieval and Renaissance Studies in honour of Robert Brian Tate. Oxford: The Dolphin Book Co., 1986, p. 47-61.

Iogna-Prat, Dominique. Ordem(ns). In: Le GofF, Jacques \& Schmitt, Jean-Claude (Coords.), Dicionário Temático do Ocidente Medieval. v. 2. São Paulo: Edusc, 2002, p. 305-319.

JoHnson, Allan G., The Blackwell dictionary of sociology: a user's guide to sociological language. Cambridge: Blackwell, 1995.

LE Goff, Jacques, A civilização do Ocidente medieval. v. 1. Lisboa: Estampa, 1995.

—, Le roi dans l'Occident Médiéval. In: Le Goff. Héros du Moyen Âge, le Saint et le Roi. Paris: Gallimard, 2004.

—, O Deus da Idade Média, Rio de Janeiro: Civilização Brasileira, 2007.

—, Rei. In: Le Goff. \& SchmitT, Jean-Claude (Coords.). Dicionário Temático do Ocidente Medieval. v. 2. São Paulo: Edusc, 2002, p. 395-414.

LeVI, Giovanni e SchmitT, Jean-Claude, História dos Jovens 1. Da Antiguidade à Era Moderna. São Paulo: Companhia das Letras, 1996.

Loyn, H. R., Dicionário da Idade Média. Rio de Janeiro: Jorge Zahar, 1997, p. 312.

MachiRANT, Francesc, «Introducció». Llibre dels fets. Jaume I. Alzira: Bromera, 2008.

Maíz Chacón, J., «La argumentación filosófica del caballero medieval. El modelo e ideal luliano em el Libre del Orde de Cavaleria». CostA, Ricardo da. TôRrEs, Moisés Romanazzi e ZIERER, Adriana. Mirabilia. Revista Eletrônica de História Antiga e Medieval, n. ${ }^{\circ}$ 05, 2005. Disponível em: http://www.revistamirabilia.com/Numeros /Num5/art4.htm. Acesso em 05 de Julho de 2009.

NAVARro, Francesc, Historia Universal. La expansión musulmana. Madrid: Salvat, s/d.

NiCOLAu D'Olwer, Lluís, La Crónica del Conqueridor i els seus problemas. Estudis Universitaris Catalans, ${ }^{\circ}{ }^{\circ} 11,1926$, p. $79-88$.

PDORREON, Romi, «Introducció». In: Jaume I. La conquista de Mallorca del Llibre dels fets. Barcelona: La Magrana, 1997.

Previté-Orton, C. W., Historia del mundo en la Edad Media. Ramon Sopena: Barcelona, 1995.

Pujol, Josep M., «El mite de l'heroi a la casa de Barcelona: Guifred, el Pelós i Jaume I». Bargalho, Maria e Zaragoza, Joana (Eds.). Mites i llegendes. Cossetània Edicions, 2002, p. 113-133.

RuIz-Domènec, José Enrique. Salvar la imagen del caballero. In: Jaime I, Rey y Caballero. Los arneses y la cultura caballeresca en el siglo XIII. València: LAIMPRENTA CG, 2008.

Rodríguez-Picavea Matilla, Enrique, Los monjes guerreiros en los reinos hispánicos. as órdenes militares en la Península Ibérica durante la Edad Media. Madrid: La esfera de los libros, 2008. 
Silva, Pedro, História e Mistérios dos Templários. Rio de Janeiro: Ediouro, 2001.

SOLER I LlOPART, Albert, Literatura catalana medieval. Barcelona: UOC, 2003.

SoldEVILA, Ferran, Els grans reis del segle XIII. Jaume I i Pere el Gran. Barcelona: Vicens-Vives, 1965.

—, «Introducció a les Quatre Grans Cròniques». Les Quatre Grans Cròniques. Barcelona: Selecta, 1971.

SPIEGEL, Gabrielle M. Genealogy: Form and Function in Medieval Historical Narrative. History and Theory, Middletown, v. 22, n. ${ }^{\circ}$ 1, p. 43-53, 1983.

Tourtoulon, Ch., Don Jaime I el Conquistador, rey de Aragón. v. 1. Valencia: Frederico Doménech, 1874.

UTRILlA Utrilla, Juan F. Jaime I (1213-1276): aspectos más sobresalientes de un reinado. In: Colón Domènech, Germá i MARTínez RoMero, Tomàs (Eds.). El rei Jaume I: fets, actes i paraules. Barcelona: Publicacions de l'Abadia de Montserrat, 2008, p. 53-73.

VAuchez, André, A Espiritualidade na Idade Média ocidental. Rio de Janeiro: Jorge Zahar, 1995.

VIANNA, Luciano J., «A cavalaria medieval e a formação inicial de Jaime I como rei cavaleiro no Llibre dels Fets (c. 1252-1274)». CosTA, Ricardo da. TôRRES, Moisés Romanazzi e ZIERER, Adriana. Mirabilia. Revista Eletrônica de História Antiga e Medieval, n. ${ }^{\circ}$ 08, 2008. Disponível em: http://www.revistamirabilia.com/Numeros/ Num8/numero8_10.htm. Acesso em 07 de Julho de 2009.

—, «Ah, Santa Maria, ajudais aos nossos, pois parece que o encontro já começou: a batalha de Portopí na conquista de Maiorca (1229)». SINAIS - Revista Eletrônica. Ciências Sociais. Vitória: CCHN, UFES, Edição n. 04, v.1, Dezembro. 2008. p. 5670.

—, «Passado, simbolismo e naturalidade: os primeiros anos de Jaime I (1208-1276) no Livro dos Feitos». Temporalidades, Revista de História, v.1, p. 195-214, 2009.

—, Pelos céus e pela terra: a conquista de Maiorca (1229) como legitimidade do rei Jaime I, o Conquistador (1208-1276). 2009. Dissertação de Mestrado. Programa de Pós-Graduação em História Social das Relações Políticas. Universidade Federal do Espírito Santo. Vitória, 2009.

—, «Simbolismo e naturalidade nos primeiros tempos do reinado de Jaime I (12081276), o Conquistador». XIV Seminario Académico APEC. Compartiendo el Conocimiento. Barcelona: Casa Amèrica Catalunya, 2009, p. 109-118.

VillaCAÑAs, José Luis, Jaume I el Conquistador. Barcelona: Espasa Calpe, 2004.

ZIERER, Adriana M. S. Paraíso, Escatologia e Messianismo em Portugal à época de D. João I. 2004. Tese de Doutorado. Programa de Pós-Graduação em História, Universidade Federal Fluminense, Niterói, 2004. 